\title{
Environmental Considerations Related to Mining of Nonfuel Minerals
}

Chapter B of

Critical Mineral Resources of the United States-Economic and Environmental Geology and Prospects for Future Supply

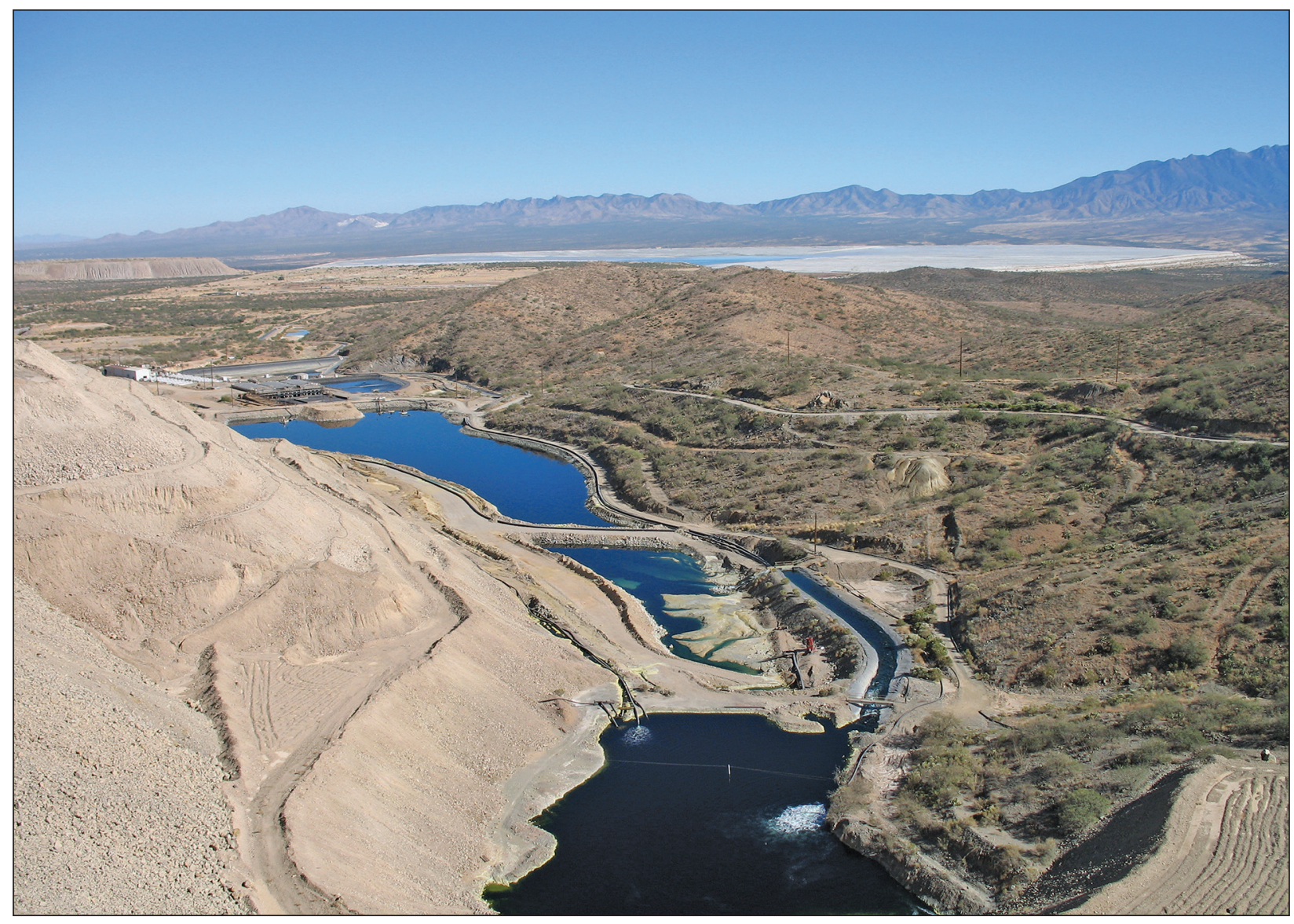

Professional Paper 1802-B 


\section{Periodic Table of Elements}

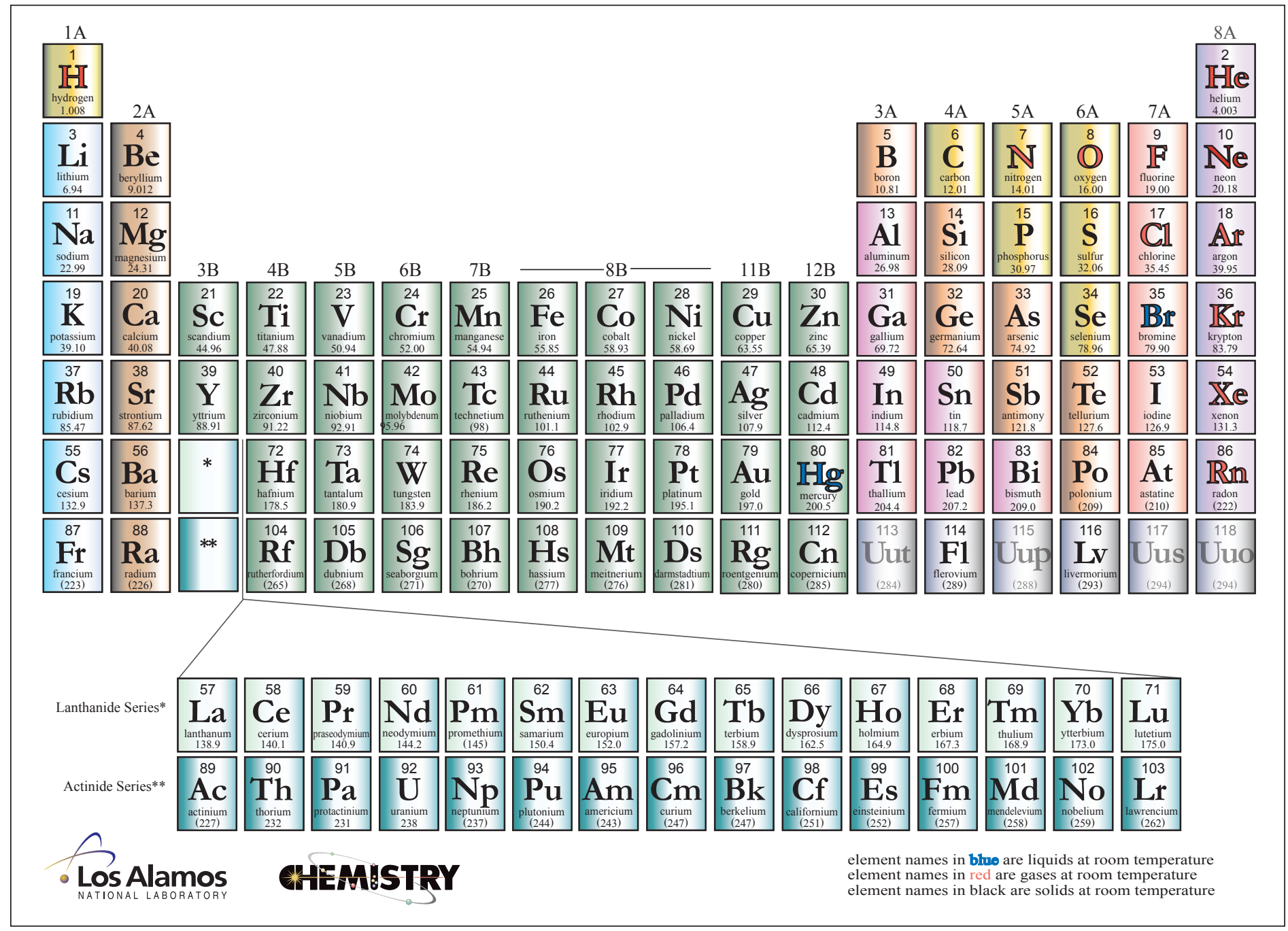

Modified from Los Alamos National Laboratory Chemistry Division; available at http://periodic.lanl.gov/images/periodictable.pdf.

Cover. Photograph of the copper solvent-extraction and electrowinning ponds (foreground) and the tailings impoundment (background) at the Sierrita copper mine in Arizona. Water management and solid-waste management are major areas of focus for environmental protection at active mines. Photograph by Robert R. Seal II. 


\section{Environmental Considerations Related to Mining of Nonfuel Minerals}

By Robert R. Seal II, Nadine M. Piatak, Bryn E. Kimball, and Jane M. Hammarstrom

Chapter B of

Critical Mineral Resources of the United States-Economic and Environmental Geology and Prospects for Future Supply

Edited by Klaus J. Schulz, John H. DeYoung, Jr., Robert R. Seal II, and Dwight C. Bradley

Professional Paper 1802-B 


\title{
U.S. Department of the Interior RYAN K. ZINKE, Secretary
}

\section{U.S. Geological Survey William H. Werkheiser, Acting Director}

\author{
U.S. Geological Survey, Reston, Virginia: 2017
}

For more information on the USGS — the Federal source for science about the Earth, its natural and living resources, natural hazards, and the environment-visit https://www.usgs.gov or call 1-888-ASK-USGS.

For an overview of USGS information products, including maps, imagery, and publications, visit https://store.usgs.gov/.

Any use of trade, firm, or product names is for descriptive purposes only and does not imply endorsement by the U.S. Government.

Although this information product, for the most part, is in the public domain, it also may contain copyrighted materials as noted in the text. Permission to reproduce copyrighted items must be secured from the copyright owner.

Suggested citation:

Seal, R.R., II, Piatak, N.M., Kimball, B.E., and Hammarstrom, J.M., 2017, Environmental considerations related to mining of nonfuel minerals, chap. B of Schulz, K.J., DeYoung, J.H., Jr., Seal, R.R., II, and Bradley, D.C., eds., Critical mineral resources of the United States-Economic and environmental geology and prospects for future supply: U.S. Geological Survey Professional Paper 1802, p. B1-B16, https://doi.org/10.3133/pp1802B.

ISSN 2330-7102 (online) 


\section{Contents}

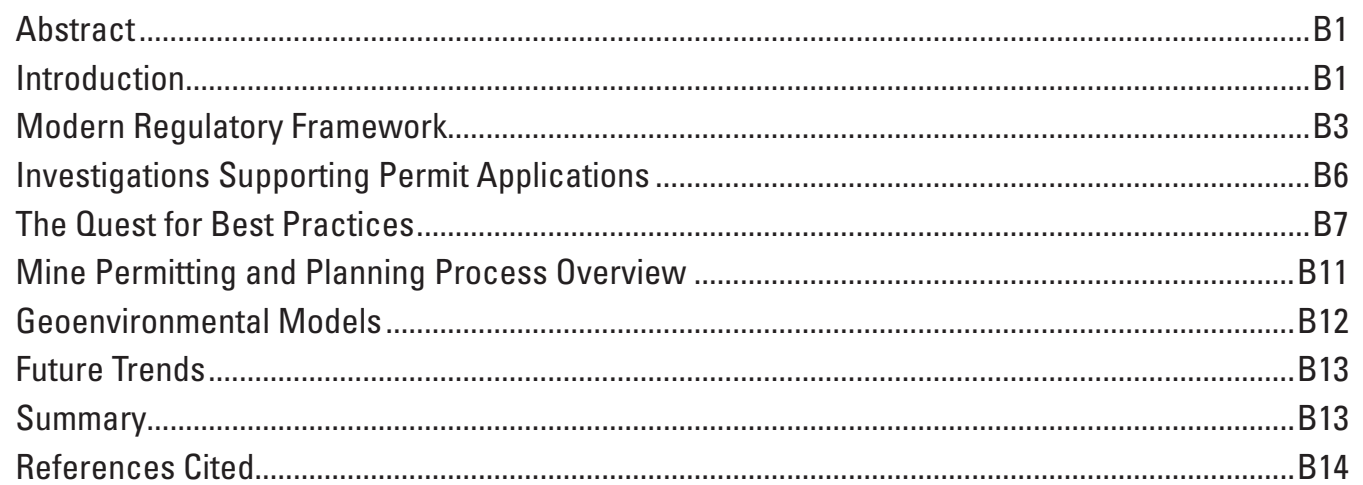

\section{Figures}

B1. Graph showing population growth and the change in supporting land area from 3500 B.C. to 2100 A.D., with projections to 2050 ..........................................................

B2. Graph showing dates associated with all the mine sites on the U.S. Environmental Protection Agency's National Priorities List

\section{Tables}

B1. Summary of selected Federal laws relevant to mine permitting ....................................B4

B2. Historical summary of mine sites placed on the U.S. Environmental Protection Agency's National Priorities List. B8

B3. Selected consortia devoted to identifying and implementing environmental best practices associated with mining 


\section{Conversion Factors}

International System of Units to Inch/Pound

\begin{tabular}{|c|c|c|}
\hline Multiply & By & To obtain \\
\hline \multicolumn{3}{|c|}{ Length } \\
\hline angstrom $(\AA)$ (0.1 nanometer) & 0.003937 & microinch \\
\hline $\operatorname{angstrom}(\AA)$ (0.1 nanometer) & 0.000003937 & mil \\
\hline micrometer $(\mu \mathrm{m})$ [or micron] & 0.03937 & mil \\
\hline millimeter (mm) & 0.03937 & inch (in.) \\
\hline centimeter $(\mathrm{cm})$ & 0.3937 & inch (in.) \\
\hline meter $(\mathrm{m})$ & 3.281 & foot $(\mathrm{ft})$ \\
\hline meter $(\mathrm{m})$ & 1.094 & yard (yd) \\
\hline kilometer $(\mathrm{km})$ & 0.6214 & mile (mi) \\
\hline \multicolumn{3}{|c|}{ Area } \\
\hline hectare (ha) & 2.471 & acre \\
\hline square kilometer $\left(\mathrm{km}^{2}\right)$ & 247.1 & acre \\
\hline square meter $\left(\mathrm{m}^{2}\right)$ & 10.76 & square foot $\left(\mathrm{ft}^{2}\right)$ \\
\hline square centimeter $\left(\mathrm{cm}^{2}\right)$ & 0.1550 & square inch $\left(\mathrm{ft}^{2}\right)$ \\
\hline square kilometer $\left(\mathrm{km}^{2}\right)$ & 0.3861 & square mile $\left(\mathrm{mi}^{2}\right)$ \\
\hline \multicolumn{3}{|c|}{ Volume } \\
\hline milliliter (mL) & 0.03381 & ounce, fluid (fl. oz) \\
\hline liter $(\mathrm{L})$ & 33.81402 & ounce, fluid (fl. oz) \\
\hline liter (L) & 1.057 & quart $(\mathrm{qt})$ \\
\hline liter $(\mathrm{L})$ & 0.2642 & gallon (gal) \\
\hline cubic meter $\left(\mathrm{m}^{3}\right)$ & 264.2 & gallon (gal) \\
\hline cubic centimeter $\left(\mathrm{cm}^{3}\right)$ & 0.06102 & cubic inch $\left(\mathrm{in}^{3}\right)$ \\
\hline cubic meter $\left(\mathrm{m}^{3}\right)$ & 1.308 & cubic yard $\left(\mathrm{yd}^{3}\right)$ \\
\hline cubic kilometer $\left(\mathrm{km}^{3}\right)$ & 0.2399 & cubic mile $\left(\mathrm{mi}^{3}\right)$ \\
\hline \multicolumn{3}{|c|}{ Mass } \\
\hline microgram $(\mu \mathrm{g})$ & 0.00000003527 & ounce, avoirdupois (oz) \\
\hline milligram (mg) & 0.00003527 & ounce, avoirdupois (oz) \\
\hline $\operatorname{gram}(\mathrm{g})$ & 0.03527 & ounce, avoirdupois (oz) \\
\hline $\operatorname{gram}(\mathrm{g})$ & 0.03215075 & ounce, troy \\
\hline kilogram (kg) & 32.15075 & ounce, troy \\
\hline kilogram (kg) & 2.205 & pound avoirdupois (lb) \\
\hline ton, metric $(\mathrm{t})$ & 1.102 & ton, short $[2,000 \mathrm{lb}]$ \\
\hline ton, metric $(\mathrm{t})$ & 0.9842 & ton, long $[2,240 \mathrm{lb}]$ \\
\hline \multicolumn{3}{|c|}{ Deposit grade } \\
\hline gram per metric ton $(\mathrm{g} / \mathrm{t})$ & 0.0291667 & ounce per short ton $(2,000 \mathrm{lb})(\mathrm{oz} / \mathrm{T})$ \\
\hline \multicolumn{3}{|c|}{ Pressure } \\
\hline megapascal (MPa) & 10 & bar \\
\hline gigapascal (GPa) & 10,000 & bar \\
\hline \multicolumn{3}{|c|}{ Density } \\
\hline gram per cubic centimeter $\left(\mathrm{g} / \mathrm{cm}^{3}\right)$ & 62.4220 & pound per cubic foot $\left(\mathrm{lb} / \mathrm{ft}^{3}\right)$ \\
\hline milligram per cubic meter $\left(\mathrm{mg} / \mathrm{m}^{3}\right)$ & 0.00000006243 & pound per cubic foot $\left(\mathrm{lb} / \mathrm{ft}^{3}\right)$ \\
\hline \multicolumn{3}{|c|}{ Energy } \\
\hline joule (J) & 0.0000002 & kilowatthour (kWh) \\
\hline joule $(\mathrm{J})$ & $6.241 \times 10^{18}$ & electronvolt (eV) \\
\hline joule $(\mathrm{J})$ & 0.2388 & calorie (cal) \\
\hline kilojoule (kJ) & 0.0002388 & kilocalorie (kcal) \\
\hline
\end{tabular}


International System of Units to Inch/Pound - Continued

\begin{tabular}{|c|c|c|}
\hline Multiply & By & To obtain \\
\hline \multicolumn{3}{|c|}{ Radioactivity } \\
\hline becquerel $(\mathrm{Bq})$ & 0.00002703 & microcurie $(\mu \mathrm{Ci})$ \\
\hline kilobecquerel (kBq) & 0.02703 & microcurie $(\mu \mathrm{Ci})$ \\
\hline \multicolumn{3}{|c|}{ Electrical resistivity } \\
\hline ohm meter $(\Omega-\mathrm{m})$ & 39.37 & ohm inch $(\Omega$-in. $)$ \\
\hline ohm-centimeter $(\Omega$-cm) & 0.3937 & ohm inch $(\Omega$-in.) \\
\hline \multicolumn{3}{|c|}{ Thermal conductivity } \\
\hline $\begin{array}{l}\text { watt per centimeter per degree } \\
\left.\text { Celsius (watt } / \mathrm{cm}^{\circ} \mathrm{C}\right)\end{array}$ & 693.1798 & $\begin{array}{l}\text { International British thermal unit } \\
\text { inch per hour per square foot per } \\
\text { degree Fahrenheit }\left(\mathrm{Btu} \text { in } / \mathrm{h} \mathrm{ft}^{2}{ }^{\circ} \mathrm{F}\right)\end{array}$ \\
\hline watt per meter kelvin (W/m-K) & 6.9318 & $\begin{array}{l}\text { International British thermal unit } \\
\text { inch per hour per square foot per } \\
\text { degree Fahrenheit (Btu in } / \mathrm{h} \mathrm{ft}{ }^{\circ} \mathrm{F} \text { ) }\end{array}$ \\
\hline
\end{tabular}

Inch/Pound to International System of Units

\begin{tabular}{|c|c|c|}
\hline \multicolumn{3}{|c|}{ Length } \\
\hline mil & 25.4 & micrometer $(\mu \mathrm{m})$ [or micron] \\
\hline inch (in.) & 2.54 & centimeter $(\mathrm{cm})$ \\
\hline inch (in.) & 25.4 & millimeter (mm) \\
\hline foot $(\mathrm{ft})$ & 0.3048 & meter $(\mathrm{m})$ \\
\hline mile (mi) & 1.609 & kilometer (km) \\
\hline \multicolumn{3}{|c|}{ Volume } \\
\hline ounce, fluid (fl. oz) & 29.57 & milliliter $(\mathrm{mL})$ \\
\hline ounce, fluid (fl. oz) & 0.02957 & liter $(\mathrm{L})$ \\
\hline \multicolumn{3}{|c|}{ Mass } \\
\hline ounce, avoirdupois (oz) & $28,350,000$ & microgram \\
\hline ounce, avoirdupois (oz) & 28,350 & milligram \\
\hline ounce, avoirdupois (oz) & 28.35 & $\operatorname{gram}(\mathrm{g})$ \\
\hline ounce, troy & 31.10348 & $\operatorname{gram}(\mathrm{g})$ \\
\hline ounce, troy & 0.03110348 & kilogram (kg) \\
\hline pound, avoirdupois (lb) & 0.4536 & kilogram (kg) \\
\hline ton, short $(2,000 \mathrm{lb})$ & 0.9072 & ton, metric $(\mathrm{t})$ \\
\hline ton, long $(2,240 \mathrm{lb})$ & 1.016 & ton, metric $(\mathrm{t})$ \\
\hline \multicolumn{3}{|c|}{ Deposit grade } \\
\hline ounce per short ton $(2,000 \mathrm{lb})(\mathrm{oz} / \mathrm{T})$ & 34.285714 & gram per metric ton $(\mathrm{g} / \mathrm{t})$ \\
\hline \multicolumn{3}{|c|}{ Energy } \\
\hline kilowatthour (kWh) & $3,600,000$ & joule $(\mathrm{J})$ \\
\hline electronvolt $(\mathrm{eV})$ & $1.602 \times 10^{-19}$ & joule $(\mathrm{J})$ \\
\hline \multicolumn{3}{|c|}{ Radioactivity } \\
\hline microcurie $(\mu \mathrm{Ci})$ & 37,000 & becquerel (Bq) \\
\hline microcurie $(\mu \mathrm{Ci})$ & 37 & kilobecquerel (kBq) \\
\hline
\end{tabular}

Temperature in degrees Celsius $\left({ }^{\circ} \mathrm{C}\right)$ may be converted to degrees Fahrenheit $\left({ }^{\circ} \mathrm{F}\right)$ as follows:

$$
{ }^{\circ} \mathrm{F}=\left(1.8 \times{ }^{\circ} \mathrm{C}\right)+32
$$

Temperature in degrees Celsius $\left({ }^{\circ} \mathrm{C}\right)$ may be converted to kelvin $(\mathrm{K})$ as follows:

$$
\mathrm{K}={ }^{\circ} \mathrm{C}+273.15
$$

Temperature in degrees Fahrenheit $\left({ }^{\circ} \mathrm{F}\right)$ may be converted to degrees Celsius $\left({ }^{\circ} \mathrm{C}\right)$ as follows:

$$
{ }^{\circ} \mathrm{C}=\left({ }^{\circ} \mathrm{F}-32\right) / 1.8
$$




\section{Datum}

Unless otherwise stated, vertical and horizontal coordinate information is referenced to the World Geodetic System of 1984 (WGS 84). Altitude, as used in this report, refers to distance above the vertical datum.

\section{Supplemental Information}

Specific conductance is given in microsiemens per centimeter at 25 degrees Celsius $(\mu \mathrm{S} / \mathrm{cm}$ at $\left.25^{\circ} \mathrm{C}\right)$.

Concentrations of chemical constituents in soils and (or) sediment are given in milligrams per kilogram (mg/kg), parts per million (ppm), or parts per billion (ppb).

Concentrations of chemical constituents in water are given in milligrams per liter $(\mathrm{mg} / \mathrm{L})$, micrograms per liter $(\mu \mathrm{g} / \mathrm{L})$, nanogams per liter $(\mathrm{ng} / \mathrm{L})$, nanomoles per kilogram $(\mathrm{nmol} / \mathrm{kg})$, parts per million (ppm), parts per billion (ppb), or parts per trillion (ppt).

Concentrations of suspended particulates in water are given in micrograms per gram $(\mu \mathrm{g} / \mathrm{g})$, milligrams per kilogram $(\mathrm{mg} / \mathrm{kg})$, or femtograms per gram $(\mathrm{fg} / \mathrm{g})$.

Concentrations of chemicals in air are given in units of the mass of the chemical (milligrams, micrograms, nanograms, or picograms) per volume of air (cubic meter).

Activities for radioactive constituents in air are given in microcuries per milliliter $(\mu \mathrm{Ci} / \mathrm{mL})$.

Deposit grades are commonly given in percent, grams per metric ton $(\mathrm{g} / \mathrm{t})$ - which is equivalent to parts per million (ppm) — or troy ounces per short ton (oz/T).

Geologic ages are expressed in mega-annum ( $\mathrm{Ma}$, million years before present, or $10^{6}$ years ago) or giga-annum ( $\mathrm{Ga}$, billion years before present, or $10^{9}$ years ago).

For ranges of years, "to" and (or) the en dash ("-") mean "up to and including."

\begin{tabular}{ll}
\multicolumn{1}{c}{ Concentration unit } & \multicolumn{1}{c}{ Equals } \\
\hline milligram per kilogram $(\mathrm{mg} / \mathrm{kg})$ & part per million \\
microgram per gram $(\mu \mathrm{g} / \mathrm{g})$ & part per million \\
microgram per kilogram $(\mu \mathrm{g} / \mathrm{kg})$ & part per billion $\left(10^{9}\right)$ \\
\hline
\end{tabular}

\section{Equivalencies}

part per million $(\mathrm{ppm}): 1 \mathrm{ppm}=1,000 \mathrm{ppb}=1,000,000 \mathrm{ppt}=0.0001$ percent part per billion (ppb): $0.001 \mathrm{ppm}=1 \mathrm{ppb}=1,000 \mathrm{ppt}=0.0000001$ percent part per trillion (ppt): $0.000001 \mathrm{ppm}=0.001 \mathrm{ppb}=1 \mathrm{ppt}=0.0000000001$ percent

\section{Metric system prefixes}

$\begin{array}{lll}\text { tera- (T-) } & 10^{12} & 1 \text { trillion } \\ \text { giga- (G-) } & 10^{9} & 1 \text { billion } \\ \text { mega- (M-) } & 10^{6} & 1 \text { million } \\ \text { kilo- (k-) } & 10^{3} & 1 \text { thousand } \\ \text { hecto- (h-) } & 10^{2} & 1 \text { hundred } \\ \text { deka- (da-) } & 10 & 1 \text { ten } \\ \text { deci- (d-) } & 10^{-1} & 1 \text { tenth } \\ \text { centi- (c-) } & 10^{-2} & 1 \text { hundredth } \\ \text { milli- (m-) } & 10^{-3} & 1 \text { thousandth } \\ \text { micro- ( } \mu-) & 10^{-6} & 1 \text { millionth } \\ \text { nano- (n-) } & 10^{-9} & 1 \text { billionth } \\ \text { pico- (p-) } & 10^{-12} & 1 \text { trillionth } \\ \text { femto- (f-) } & 10^{-15} & 1 \text { quadrillionth } \\ \text { atto- (a-) } & 10^{-18} & 1 \text { quintillionth }\end{array}$




\section{Abbreviations and Symbols}

$\begin{array}{ll}\text { ADTI } & \text { Acid Drainage Technology Initiative } \\ \text { CERCLA } & \text { Comprehensive Environmental Response, Compensation, and Liability Act } \\ \text { EA } & \text { environmental assessment } \\ \text { EIS } & \text { environmental impact statement } \\ \text { EPA } & \text { U.S. Environmental Protection Agency } \\ \text { FONSI } & \text { finding of no significant impact } \\ \text { GARD } & \text { Global Acid Rock Drainage } \\ \text { INAP } & \text { International Network for Acid Prevention } \\ \text { km² } & \text { square kilometer } \\ \text { m } & \text { meter } \\ \text { MEND } & \text { Mine Environment Neutral Drainage } \\ \text { NEPA } & \text { National Environmental Policy Act } \\ \text { NPL } & \text { National Priorities List (Superfund) } \\ \text { U.S.C. } & \text { U.S. Code } \\ \text { USGS } & \text { U.S. Geological Survey }\end{array}$





\title{
Environmental Considerations Related to Mining of Nonfuel Minerals
}

\author{
By Robert R. Seal II, Nadine M. Piatak, Bryn E. Kimball, and Jane M. Hammarstrom
}

\section{Abstract}

Throughout most of human history, environmental stewardship during mining has not been a priority partly because of the lack of applicable laws and regulations and partly because of ignorance about the effects that mining can have on the environment. In the United States, the National Environmental Policy Act of 1969, in conjunction with related laws, codified a more modern approach to mining, including the responsibility for environmental stewardship, and provided a framework for incorporating environmental protection into mine planning. Today, similar frameworks are in place in the other developed countries of the world, and international mining companies generally follow similar procedures wherever they work in the world. The regulatory guidance has fostered an international effort among all stakeholders to identify best practices for environmental stewardship.

The modern approach to mining using best practices involves the following: (a) establishment of a pre-mining baseline from which to monitor environmental effects during mining and help establish geologically reasonable closure goals; (b) identification of environmental risks related to mining through standardized approaches; and (c) formulation of an environmental closure plan before the start of mining. A key aspect of identifying the environmental risks and mitigating those risks is understanding how the risks vary from one deposit type to another-a concept that forms the basis for geoenvironmental mineral-deposit models.

Accompanying the quest for best practices is the goal of making mining sustainable into the future. Sustainable mine development is generally considered to be development that meets the needs of the present generation without compromising the ability of future generations to meet their own needs. The concept extends beyond the availability of nonrenewable mineral commodities and includes the environmental and social effects of mine development.

Global population growth, meanwhile, has decreased the percentage of inhabitable land available to support society's material needs. Presently, the land area available to supply the mineral resources, energy resources, water, food, shelter, and waste disposal needs of all Earth's inhabitants is estimated to be 135 square meters per person. Continued global population growth will only increase the challenges of sustainable mining.

Current trends in mining are also expected to lead to new environmental challenges in the future, among which are mine-waste management issues related to mining larger deposits for lower ore grade; water-management issues related to both the mining of larger deposits and the changes in precipitation brought about by climate change; and greenhouse gas issues related to reducing the carbon footprint of larger, more energy-intensive mining operations.

\section{Introduction}

The development of mining was coincident with the beginning of the Stone Age when, more than 2.5 million years ago, ancestors of the human race first began fashioning tools out of stone. At the time, survival was likely the highest priority, and the health of the environment and the effects that mining had on it were likely of little, if any, concern. The world was probably considered vast and able to tolerate the seemingly minor effects of mining. This attitude has persisted for most of human history.

Early cultural development was punctuated by advances in mining and metallurgy (the science of extracting metals from ores). The Stone Age gave way to the Bronze Age roughly 5,300 years ago when use of weapons and implements made of bronze - an alloy of copper and tin - became widespread. The manufacture of bronze required not only the mining of copper and tin, but the smelting of it; that is, the extraction of the metal from ore minerals using heat. The Bronze Age was followed by the Iron Age roughly 3,200 years ago. The Iron Age is defined by the widespread use of weapons and implements made of iron. The smelting of iron ores requires much higher temperatures than does the smelting of copper or tin. Cultural milestones in human history have been accompanied by advances in mining and metallurgical methods and technologies, even down to the present day, and the need for mining and metallurgy is likely to endure far into the future. 
Evidence of the historical or prehistoric influence of mining on the environment is limited, and indications of significant societal concern about the environmental impacts of mining are even more scarce. Sediment cores from peat bogs, estuaries, lakes, and ice cores indicate that the dispersion of metals from mining and early smelting date back at least 5,000 years (Shotyk and others, 1996; Rosman and others, 1997; Leblanc and others, 2000; Lee and others, 2008; Lottermoser, 2010). In Georgius Agricola's landmark treatise on mining and metallurgy titled "De Re Metallica" [On the Nature of Metals (Minerals)], which was published in 1556, a year after his death, the author notes that ".... when the ores are washed, the water which has been used poisons the brooks and streams, and either destroys the fish or drives them away" (Agricola, 1950/1556).

In the United States, the earliest significant court case involving a dispute about the environmental impacts of mining concerned hydraulic mining of gravels in the Mother Lode gold belt of the Sierra Nevada Mountains. Hydraulic mining uses high-pressure "cannons" to direct water to erode ancient stream gravels and move the eroded sediment into channels where gold can be efficiently separated. Farmers in the Sacramento Valley of California filed lawsuits against hydraulic mining companies because of the effects that the sediment from the hydraulic gold mining was having on farmland downstream from the mines. This legal battle culminated with the Sawyer Decision in 1884, which effectively banned hydraulic mining (Kelley, 1956).

In the Eastern United States, significant legal action surrounded ore processing practices in the Copper Basin (or Ducktown Basin) mining district in Tennessee (Quinn, 1993). Numerous lawsuits filed between 1890 and 1930 focused on air pollution initially related to the open roasting of sulfide ores as preparation for copper smelting and, later, to the smelting itself. The released sulfur dioxide resulted in acid rain throughout the surrounding 250-square-kilometer $\left(\mathrm{km}^{2}\right)$ area, which destroyed much of the vegetation and led to extensive soil erosion. The long series of lawsuits ultimately reached the U.S. Supreme Court, which ruled against the mining companies. The Ducktown case was especially noteworthy in that it was the first air pollution case to be heard by the U.S. Supreme Court. The numerous lawsuits had the positive effect of encouraging the development of acid converters, which capture sulfur dioxide emissions from roasting and smelting and convert them to sulfuric acid, which is a valuable byproduct.

Today, the National Environmental Policy Act of 1969 (NEPA) (42 U.S.C. §4321 et seq.) serves as the basic national charter for environmental protection. Its passage represents a milestone in the history of environmental protection with respect to mining practices, and its effect has been significant for society, the mining industry, and the environment.

The realization that the environmental effects of mining done without regard for the environment cannot be absorbed by nature has been building for at least the past several centuries. The problem can be conceptualized using the idea of a "support square," as described by Skinner (1989), and amplified by Rutland (1997). A support square is equal to the hypothetically inhabitable area of the world divided by the population of the world; hence, the size of a support square is determined by the global population density. A support square represents the inhabitable land area needed to support all the resource needs of one human being. These needs include mineral resources, food, water, shelter, recreation, and waste disposal. If areas permanently covered by ice and areas above 5,000 meters $(\mathrm{m})$ are excluded, the inhabitable area of the world is roughly $133,000,000 \mathrm{~km}^{2}$.

Figure B1 illustrates how the size of the support square has changed over time as the population density of the planet has increased. Beginning with the Bronze Age, roughly 5,300 years ago (3300 B.C.), when the population of the world is estimated to have been 14 million people, each support square would have covered an area of $9.5 \mathrm{~km}^{2}$, or be approximately 3,080 $\mathrm{m}$ on a side. By the time Christopher Columbus discovered America (1492), the side of the support square was reduced to $560 \mathrm{~m}$. When the Declaration of Independence was signed in 1776 , the square was down to $400 \mathrm{~m}$ on a side. Today, the support square is only $135 \mathrm{~m}$ on a side and, by 2050 , more than $15 \mathrm{~m}$ is projected to be lost, leaving a square of only $119 \mathrm{~m}$ on a side to support an individual. In other words, society currently has only 11 percent of the per capita land area that it had in 1776, 6 percent of the per capita land area that it had when Columbus discovered America, and 0.2 percent of the per capita land area that it had at the beginning of the Bronze Age. This trend will continue with the currently projected population growth. Improved environmental stewardship during mining and all other extractive activities is essential to maintaining the quality of the land area available for use.

Responsible environmental stewardship related to mining is embodied in the concept of "sustainable mining." The term sustainable mining strikes many as an oxymoron, because it is commonly used in reference to the mining of nonrenewable mineral or energy resources. Sustainable development, or sustainability, however, is generally defined as the ability to meet current needs without hindering future generations from meeting their needs (Brundtland, 1987). Sustainable practices for mining have come to focus on the environmental, economic, and social well-being in areas where mining is proposed or is taking place. The environmental part typically includes aspects of water management, solid-waste management, reagent use and recycling, and greenhouse gas emissions (Mudd, 2008, 2010). This chapter presents an overview of environmental practices related to the permitting and development of active and new mines, and provides a context for the environmental considerations sections of the commodity-focused chapters in this book. 


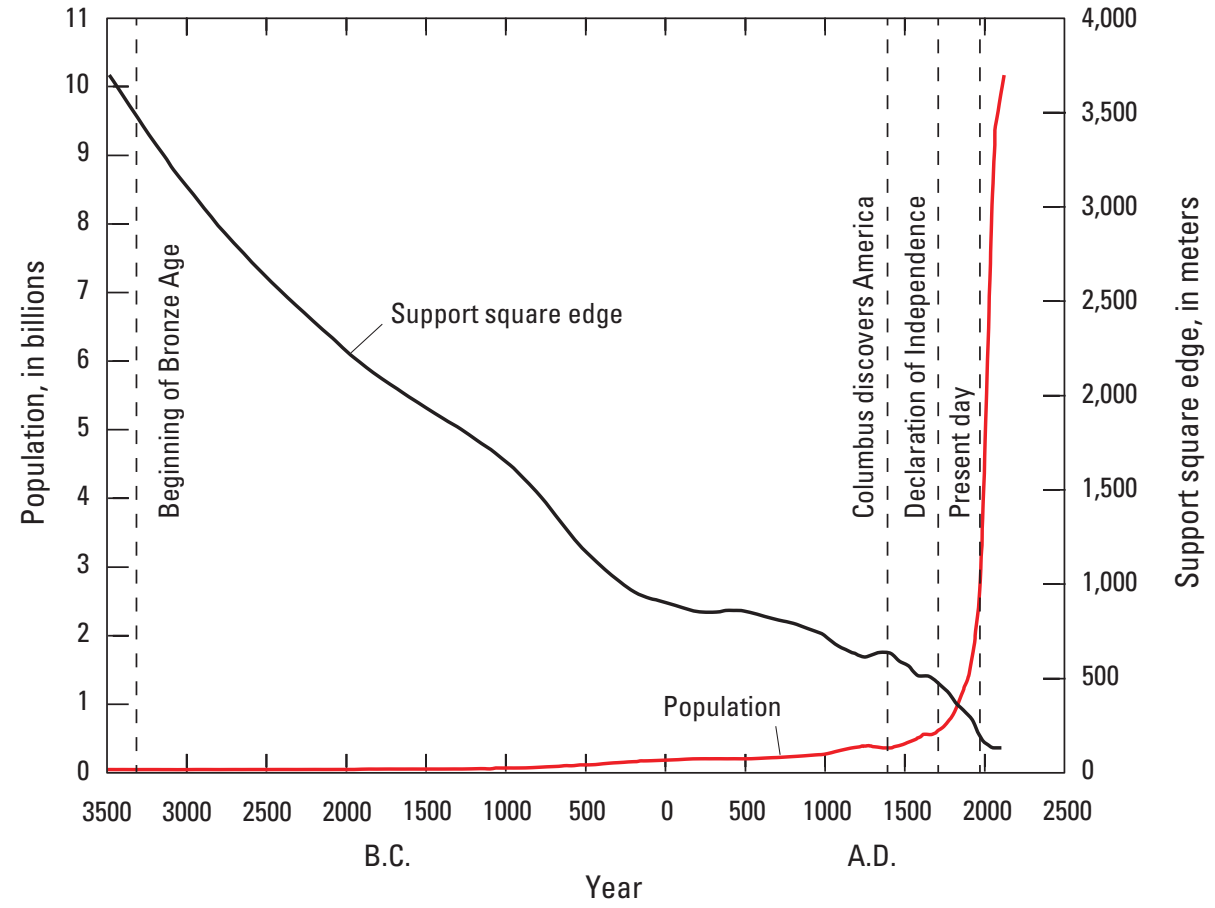

Figure B1. Graph showing population growth and the change in supporting land area from 3500 B.C. to 2100 A.D., with projections to 2050 . The support square edge (in meters $[\mathrm{m}]$ ) represents the amount of inhabitable land available to support each person alive on Earth. In 2016, the hypothetical support square was $135 \mathrm{~m}$ on a side; by 2050, the projected support square will have decreased to $119 \mathrm{~m}$ on a side. Based on projections by Skinner (1989) and Rutland (1997).

\section{Modern Regulatory Framework}

The regulatory framework for mine permitting in the United States is similar to that of other developed nations, but mining regulations in developing nations have tended to be absent or relatively weak. With globalization, however, less developed countries, such as Chile, where mining is a significant component of the gross domestic product, are reviewing and extending existing regulations to become more aligned with those of global partners, such as the United States, Canada, and the European Union (Espejo and others, 2012). Furthermore, major international mining companies generally follow similar approaches wherever they work, regardless of the presence or absence of local regulations. The following describes the development of the modern regulatory framework in the United States.

The National Environmental Policy Act of 1969 (NEPA), which was signed into law on January 1, 1970, serves as a basic national charter for environmental protection. It led to the establishment of the U.S. Environmental Protection Agency (EPA) in December 1970. The law provides the framework that Federal Government agencies use to evaluate the environmental effects of proposed Federal actions, such as the issuance of permits for mining or other industrial activities. An example of a specific action related to mining includes the issuing of permits for such mining-related activities as water withdrawal, exploratory drilling, wetland and (or) stream modifications, the transport of chemicals, and mine construction, among others. The framework put in place with the passage of the NEPA is known as the
"NEPA process" - a process that is used to evaluate the environmental effects of Federal projects or actions, including alternative actions. The NEPA process is a staged approach in which, in the absence of a categorical exclusion, an environmental assessment (EA) is performed and results in either a "finding of no significant impact" (FONSI) or a determination that an environmental impact statement (EIS) is required. A categorical exclusion classifies the action as not having a significant effect on environmental quality. An EA is a preliminary evaluation of the potential magnitude of environmental effects and alternatives. The identification in the EA of a potential for significant environmental impact leads to the requirement for an EIS. An EIS is a detailed assessment of potential environmental impacts and alternatives. A Federal land-management or regulatory agency may skip the initial steps of the NEPA process if it feels that a significant potential for adverse environmental impact exists and may proceed directly to requiring the preparation of an EIS. Proposed mining projects that require the action of a Federal agency typically result in the requirement for an EIS.

The passage of the NEPA led to the passage of additional legislation that provides the modern policy for environmental protection associated with mining and other commercial and industrial activities. In one example, a previous law - the General Mining Law of 1872, which had been enacted to promote development and settlement of publicly owned lands in the Western United States - had provisions for environmental protection; in follow-on legislation, the Federal Land Policy and Management Act of 1976 (43 U.S.C. §1701 et seq.) was passed to address such issues as the requirement for mine reclamation 
and its financial assurance. The NEPA process relies on these other laws and regulations to ensure that the potential for significant environmental impacts is addressed. The major laws relevant to proposed mining projects commonly include the Clean Water Act (33 U.S.C. §1251 et seq.), the Safe Drinking Water Act (42 U.S.C. $\$ 300 \mathrm{f}$ et seq.), the Clean Air Act (42 U.S.C. $\$ 7401$ et seq.), and the Endangered Species
Act (16 U.S.C. $\$ 1531$ et seq.), although many others may be relevant. Salient features of these acts are summarized in table B1. The Resource Conservation and Recovery Act (1976) (42 U.S.C. $\$ 6901$ et seq.), which governs the disposal of solid and hazardous wastes, specifically exempts waste generated during the extraction, beneficiation, and processing of minerals from regulation as hazardous waste.

Table B1. Summary of selected Federal laws relevant to mine permitting.

[EPA, U.S. Environmental Protection Agency]

\begin{tabular}{|c|c|c|c|}
\hline Act (abbreviation) & $\begin{array}{l}\text { Year } \\
\text { signed }\end{array}$ & Purpose & Implementation \\
\hline $\begin{array}{l}\text { National Environmental Policy Act of } 1969 \text { (NEPA) } \\
\text { (42 U.S.C. \$4321 et seq.), and amendments } \\
\text { https://www.gpo.gov/fdsys/pkg/USCODE-2014-title42/ } \\
\text { pdf/USCODE-2014-title42-chap55.pdf } \\
\text { See also: http://www2.epa.gov/laws-regulations/ } \\
\text { summary-national-environmental-policy-act } \\
\text { and } \\
\text { http://www.epa.gov/compliance/nepa/ }\end{array}$ & 1970 & $\begin{array}{l}\text { Promotes efforts that will prevent } \\
\text { or eliminate damage to the } \\
\text { environment and biosphere } \\
\text { and stimulate the health and } \\
\text { welfare of humankind by } \\
\text { providing information to } \\
\text { the public. }\end{array}$ & $\begin{array}{l}\text { EPA reviews documents to } \\
\text { determine if the environmental } \\
\text { alternative chosen will affect } \\
\text { the environment and to } \\
\text { determine if the agency that } \\
\text { wrote the documents provided } \\
\text { this information to the public. }\end{array}$ \\
\hline $\begin{array}{l}\text { Clean Water Act (CWA) (33 U.S.C. } § 1251 \text { et seq.), } \\
\text { and amendments } \\
\text { https://www.gpo.gov/fdsys/pkg/USCODE-2014-title33/ } \\
\text { pdf/USCODE-2014-title33-chap26.pdf } \\
\text { See also: http://www2.epa.gov/laws-regulations/ } \\
\text { summary-clean-water-act }\end{array}$ & 1972 & $\begin{array}{l}\text { Restores and maintains the } \\
\text { chemical, physical, and } \\
\text { biological integrity of the } \\
\text { Nation's waters; also } \\
\text { protects wetlands. }\end{array}$ & $\begin{array}{l}\text { EPA provides guidance to States } \\
\text { and tribes on the concentra- } \\
\text { tions of metals that will not } \\
\text { harm aquatic life or human } \\
\text { health so State and tribal } \\
\text { governments can set standards. }\end{array}$ \\
\hline $\begin{array}{l}\text { Safe Drinking Water Act of } 1974 \text { (SDWA) } \\
\text { (42 U.S.C. \$300f et seq.), and amendments } \\
\text { https://www.gpo.gov/fdsys/pkg/USCODE-2014-title42/ } \\
\text { pdf/USCODE-2014-title42-chap6A.pdf } \\
\text { See also: http://www2.epa.gov/laws-regulations/ } \\
\text { summary-safe-drinking-water-act } \\
\text { and } \\
\text { http://water.epa.gov/lawsregs/rulesregs/sdwa/ } \\
\text { index.cfm }\end{array}$ & 1974 & $\begin{array}{l}\text { Ensures safe drinking water } \\
\text { for the public. }\end{array}$ & $\begin{array}{l}\text { EPA sets legal limits on the } \\
\text { levels of certain contaminants } \\
\text { in treated drinking water and } \\
\text { provides oversight for States } \\
\text { and tribes for implementing } \\
\text { these standards. }\end{array}$ \\
\hline $\begin{array}{l}\text { Clean Air Act (CAA) (42 U.S.C. } \$ 7401 \text { et seq.), } \\
\text { and amendments } \\
\text { https://www.gpo.gov/fdsys/pkg/USCODE-2014-title42/ } \\
\text { pdf/USCODE-2014-title42-chap85.pdf } \\
\text { See also: http://www2.epa.gov/laws-regulations/ } \\
\text { summary-clean-air-act } \\
\text { and } \\
\text { http://www.epa.gov/air/caa/ }\end{array}$ & 1963 & $\begin{array}{l}\text { Ensures clean air at a national } \\
\text { level by controlling air } \\
\text { pollution. }\end{array}$ & $\begin{array}{l}\text { EPA develops and enforces } \\
\text { regulations to protect } \\
\text { the public from airborne } \\
\text { contaminants. }\end{array}$ \\
\hline $\begin{array}{l}\text { Endangered Species Act (16 U.S.C.\$1531 et seq.), } \\
\text { and amendments } \\
\text { https://www.gpo.gov/fdsys/pkg/USCODE-2014-title16/ } \\
\text { pdf/USCODE-2014-title16-chap35.pdf } \\
\text { See also: http://www2.epa.gov/laws-regulations/ } \\
\text { summary-endangered-species-act } \\
\text { and } \\
\text { http://www.fws.gov/endangered/laws-policies/ }\end{array}$ & 1973 & $\begin{array}{l}\text { Ensures that any action author- } \\
\text { ized, funded, or carried out by } \\
\text { a Federal agency is not likely } \\
\text { to jeopardize the continued } \\
\text { existence of any listed species } \\
\text { or result in the destruction or } \\
\text { adverse modification of critical } \\
\text { habitat of such species. }\end{array}$ & $\begin{array}{l}\text { The U.S. Fish and Wildlife } \\
\text { Service (FWS) or the National } \\
\text { Marine Fisheries Service } \\
\text { (NMFS), depending upon } \\
\text { location of the site, evaluates } \\
\text { potential risks to threatened } \\
\text { and endangered species } \\
\text { through consultation with } \\
\text { other Federal agencies. }\end{array}$ \\
\hline
\end{tabular}


The Comprehensive Environmental Response, Compensation, and Liability Act (CERCLA) (42 U.S.C. \$9601 et seq.), commonly known as "Superfund," can apply to mines during production or after closure. The EPA conducts and supervises investigations and cleanup actions at mine sites where hazardous substances have been released into the environment or when there is a threat of release. The CERCLA authorizes the following two types of response actions: long-term (remedial) cleanup and short-term (removal) cleanup. Cleanups may be done by the EPA; by other Federal agencies, such as the Bureau of Land Management or the U.S. Forest Service; States or municipalities; or the mining company or parties responsible for the contamination.

A key aspect of the NEPA process for mine permitting is the prediction of potential environmental impacts related to a proposed mining project as well as predictions regarding environmental conditions after mine closure. Information about the environmental characteristics of mineral deposits, mines, and resource extraction is available from a variety of sources; however, the types and sources of this information should be considered in an appropriate context. All information has value, but its usefulness has limitations. The types of information from various sources include studies of historical abandoned mines, studies in support of mine permit applications designed to "predict" mine waste behavior, studies of modern mines permitted under the NEPA or similar environmental regulations, studies of mines that began operation prior to NEPA, and studies of mines in developing countries.

Information from historical abandoned mines is useful for several reasons. In many cases, they represent "natural experiments" that have been underway for decades, centuries, or even millennia - time scales that are impossible to reproduce in the laboratory. Many of these historical mines were developed with no consideration for environmental protection because that was not a requirement for mine permitting, and because the full environmental ramifications of mining activities probably were not fully appreciated. As such, these sites may reflect "worst case" scenarios. Information from these sites has limitations, however, because certain deposit types may no longer be mined for specific mineral commodities, or mining and ore-processing methods may have changed. Thus, the nature of modern mine waste can be quite different from that at historical mines.

For example, the abandoned Elizabeth copper mine in Vermont was initially operated in the early to middle 1800 s as a source of copperas (ferrous sulfate heptahydrate$\mathrm{FeSO}_{4} \cdot 7 \mathrm{H}_{2} \mathrm{O}$ ), which served a variety of uses - as a disinfectant, dye, as dye mordant, and as a wood preservative. Copperas production ceased at the Elizabeth Mine in the 1880s as less expensive sources became available from the steel industry (Kierstead, 2001). The copperas was produced by controlled roasting of pyrrhotite $\left(\mathrm{Fe}_{1-\mathrm{x}} \mathrm{S}\right)$ accompanied by leaching of the resulting ferrous sulfate, which was then reconstituted as solid crystals in evaporation vats. When built in the 1800 s, these copperas roast beds were designed to encourage the oxidation of sulfide minerals and to drain leachate. These features contributed to the environmental legacy of the abandoned Elizabeth copper mine because acid mine drainage is the result of the oxidation of sulfide minerals, principally pyrite $\left(\mathrm{FeS}_{2}\right)$ and pyrrhotite, in the presence of water. Surface water and groundwater from the historical copperas roast beds had the worst water quality of all waters at the site in terms of low $\mathrm{pH}$ and high concentrations of potentially toxic dissolved metals (Seal and others, 2001). In contrast, seepage at the base of a mill tailings pile that was produced using more modern techniques from 1942 to 1958 (the pile contains fine-grained reject material from which the ore minerals have been removed) and deposited lower in the stream valley, had near neutral $\mathrm{pH}$, and the water-quality issues were restricted to high concentrations of dissolved iron and sulfate. Therefore, for the same ore, historical processing techniques and modern processing techniques may result in significantly different environmental impacts.

Other sources of useful information about the environmental characteristics of ore deposits and mines are the environmental impact statements and related documents associated with mine permit applications. These documents include geochemical and other data about pre-mining conditions, which are crucial for environmental monitoring during and after mining and for setting environmental closure goals. They also contain information about the environmental characteristics of expected mine waste, the acid-generating potential of various types of solid mine wastes, and the leachability of trace elements from these wastes. These documents make predictions about future environmental conditions to aid in the permit decisionmaking process, both for scenarios in which mitigation measurements are successfully implemented and those in which they are not implemented.

Case studies of modern mines in the United States permitted under the NEPA process are scarce in the scientific literature. Instead, some data may be found in publicly available EISs associated with mine expansion projects; for example, the Aqqaluk project at the Red Dog zinc mine in Alaska (Tetra Tech, Inc., 2009). These sources generally constitute representative information about the environmental characteristics of active mines. Mining operations in many developing countries do not adhere to the same standards followed in the United States and by major international mining companies worldwide, however. Therefore, environmental data from developing countries may not be an accurate reflection of international consensus on "best practices" for environmental protection.

Even more challenging is establishing a proper context for the environmental information available for historical mines that started mining before NEPA but that have continued to produce into more recent times. It is often difficult to distinguish historical legacy issues from effects related to modern mining activity, especially if data about specific sampling sites are not reported in sufficient detail. The issue of distinguishing legacy environmental signatures is especially problematic when trying to establish closure goals for mine sites that began operations before the era of more-extensive regulation (Alpers and Nordstrom, 2000; Nordstrom, 2008). 


\section{Investigations Supporting Permit Applications}

Mine permitting is a prescribed process under the NEPA. The NEPA process as applied to mining places an emphasis on protecting water resources through the Clean Water Act. The EPA guidance is summarized in "EPA and Hardrock MiningA Source Book for Industry in the Northwest and Alaska" (U.S. Environmental Protection Agency, 2003). The source book outlines an approach to evaluating the potential risks to water quality posed by mining. A key distinction between mining and other types of industrial, commercial, or municipal development is that a mine needs to be adapted to the site conditions where the ore deposit occurs. In contrast, factories, shopping malls, airports, and schools tend to be built on tracts of land that meet a variety of specific criteria to ensure safe development and protection of the environment and the public.

The EPA source book has largely been adopted by the international mining community to serve as an outline for premining environmental studies. It also forms the foundation of the following discussion. The Source Book describes a variety of data collection, testing, mine design, and data analysis methods necessary to accomplish a rigorous assessment. The approach requires that, as part of the permitting process, premining baseline conditions must be documented, ecosystem and human health risks must be assessed, and predictions must be made about post-closure environmental conditions through a mining impact assessment. Specific topics include impacts to surface water and groundwater hydrology, impacts to water quality, impacts to aquatic resources, and impacts to wetlands. Ecological and human health risks associated with nonaqueous pathways, such as windblown dusts, are also considered.

Mining operations have the potential to affect both surface-water and groundwater hydrology at the mine site and within the broader watershed. Therefore, it is essential to evaluate whether or not impacts will be expected and what their nature and extent will be. Necessary input for this assessment includes meteorological and hydrologic data and water-management plans for operational and post-closure phases, with the goal of determining a detailed water balance for the project. Meteorological and hydrologic data are best collected on a regular basis to capture seasonal and year-toyear variations and to characterize the duration and intensity of storm events. These pre-mining data provide a baseline from which to monitor changes brought about by mining and other effects, such as climate change. Surface-water and groundwater resources are required to be thoroughly characterized, including the establishment of surface-water monitoring sites and the installation of monitoring wells. Water-management plans describe how process water, mine drainage, and storm water are handled during mining and after closure.

Mining also has the potential to affect surface-water and groundwater quality during mining and after closure. A key aspect of evaluating potential impacts to water quality and other ecosystem services and human health is the detailed geochemical characterization of pre-mining baseline conditions in surface water, groundwater, sediments, and soils. Ore deposits represent anomalous concentrations of a variety of elements that typically go beyond the mineral commodities that are the focus of mining. These chemical anomalies can be manifested in all media (rock, water, soil, sediment, and biota) in the vicinity of the mine site and represent a natural part of these ecosystems. Because elevated concentrations are part of the natural ecosystem, these concentrations represent more realistic closure goals than generic regulatory guidelines.

Mine-waste characterization and designing a mine-waste management plan are important aspects of assessing the potential for water-quality impacts. There are several types of mine waste, and mine-waste characterization is commonly done in a staged approach. Materials that are characterized include waste rock (material removed to access the ore), spent ore, and the rock that forms the walls of the pit, if open pit mining is used to produce the ore. Spent ore can be either tailings or leach-pad waste (residue from moderately crushed rock that has had metals leached from it by reactive solutions). Tailings generally result from the concentration of ores from basemetal (such as copper, lead, zinc, and nickel) and other metal (such as iron, and some uranium, gold, and silver) mines. Ore is crushed to sand or silt size and transferred to vats that contain surfactant solutions. The vats are aerated, which produces bubbles in the solution. Specific minerals adhere to the bubbles, which rise to the top and are skimmed off. Depending on the specific ore and the chemical additives used, either ore minerals or gangue (waste) minerals will rise to the top. The waste, or tailings, from this process is disposed of in a variety of ways. Tailings can be pumped as a slurry to tailings ponds, dried and stacked in piles, or mixed with a binder and disposed of as a paste, which then solidifies. Leach-pad wastes are commonly associated with many copper, gold, silver, and uranium deposits. Ore is crushed and placed on impermeable liners, where it is leached with solutions designed to extract the mineral commodities of interest. Copper is commonly leached with a sulfuric acid solution, whereas gold and silver are leached with a cyanide solution. The leach pad residues are usually left in place for disposal, and a new pad is constructed for new ore. Closure of spent piles may involve regrading the pile and (or) capping it.

The potential mine waste is characterized using several types of tests. It is common for tests to be conducted on cores from exploratory drilling and on reject material from preliminary metallurgical testing. Acid-generating potential is a major concern for some types of ores and associated wastes because of their specific mineralogical and geochemical characteristics. One type of test is known as "acid-base accounting" and is used to estimate the ability of the material either to generate acid or to neutralize it. The mineral pyrite - fool's gold - is the main source of acid mine drainage, so the test estimates its abundance on the basis of the amount of sulfur in a sample. These tests estimate only the maximum acid-generating potential of a sample because a number of factors can limit the rate of acid-mine-drainage production. 
Acid-base accounting is categorized as a "static" test, because it is based on a single set of tests. In contrast, leaching tests of potential mine-waste material that span multiple weeks or years are known as "kinetic" tests. Kinetic tests not only provide information about the acid-generating potential of mine waste but also provide insights about the leachability of metals and other trace elements from the mine waste, as well as a timeframe for the reactions to occur. Humidity-cell tests are an example of a kinetic test. Humidity-cell tests, in which a sample is leached successively on a weekly basis in laboratory experiments that span weeks or years, provide better information about the ability of waste materials to produce acid and leach environmentally important trace elements. Laboratory kinetic tests can be improved upon by constructing similar experiments at a larger scale in the field. Here, the waste material is exposed to the natural variations of temperature and precipitation that the actual mine waste will be subject to rather than the constant, somewhat artificial conditions imposed by the bench-top experimental protocols. In any case, insights gained from pre-mining mine-waste characterization are typically refined as experience is gained during mine operation.

A mining impact assessment also requires that a number of design features be considered when evaluating potential impacts to water quality. Hydrologic characterization of mines is essential for understanding the risks associated with pit lakes or underground mine waters, and hydrologic characterization of the waste facilities provides insights about the exposure of surface water and groundwater to solid waste. Facilities have to be designed not only to accommodate typical seasonal variations in the amount of precipitation, but they also must be able to handle less common 500-year floods. The water-management, solid-waste-management, and wastewatermanagement plans are also critical. Permit applications are required to describe closure and reclamation plans, how these plans affect water quantity and quality, and what the long-term needs for active or passive treatment of the water will be. These details include the final state of waste-rock piles and tailing storage facilities, such as the nature of post-closure covers, and plans to manage drainage flows off or out of waste piles. Likewise, predictions must be made regarding long-term water quality in planned pit lakes.

Mining also has the potential to affect aquatic ecosystem resources adversely in a variety of ways that must be evaluated and described during the permitting process. Baseline characterization is needed to describe pre-mining fish and aquatic macro-invertebrate populations. Mine construction can affect riparian areas and influence infiltration. Water needed for ore processing and beneficiation can influence stream flow. Water-management structures, such as ditches and trenches, can channel the flow and influence the natural balance of erosion and sedimentation in a watershed, which can impair aquatic habitat. Dams and other barriers can impede the fish movement. Accidental releases of process water or mine drainage can degrade quality and affect aquatic biota. Plans for water treatment during operation and after closure must be described. All these factors are considered as part of the permitting process.

Wetlands represent a special case for potential impacts associated with mining because they are explicitly regulated under the Clean Water Act. They perform a variety of important environmental management and filtration functions, including groundwater recharge and discharge, flood storage and moderation, sediment trapping, and nutrient trapping and removal, and they provide habitat. The mine permitting process requires that wetland resources be fully documented.

\section{The Quest for Best Practices}

As previously noted, 1970 marks both the founding of the EPA and the start of the NEPA process that provided an environmental planning framework for modern mining sites. Passage of this law sparked a review of and an evolution in mining practices meant to protect the environment, and that review continues today. One measure of the success of the law and how it has improved environmental practices associated with metal mining in the United States is the decreased number of mining sites being designated as Superfund sites.

The EPA uses the Hazard Ranking System of CERCLA to evaluate the level of contamination at a site (U.S. Environmental Protection Agency, 2016). The Hazard Ranking System is a numerical screening system that assesses potential impacts to both human and environmental (ecological) health. It considers groundwater, surface water, soil, and air. The assessments are made to determine whether the level of contamination at a site is severe enough to warrant inclusion on the EPA's National Priorities List (NPL) (U.S. Environmental Protection Agency, 2015). Placement on the NPL designates a site as eligible for cleanup under the Federal Superfund program.

The NPL includes both mine sites and related facilities, such as smelters and mineral storage facilities. In the following discussion, only mine sites are addressed, however, because smelters and storage facilities lack the intimate link to local geologic and environmental conditions that mines do and can be located at some distance from a mine site. Furthermore, understanding the environmental impacts at modern mines that have also had historical production can be complicated by legacy issues that are unrelated to modern mining practices. Nonetheless, the history of site placement on the NPL can be considered an indication of the progress that has been made in environmental protection associated with mine development since the passage of the NEPA.

The first listing of mine sites on the NPL (that is, as Superfund sites) was published in 1983; all the mines listed in that year were old mines that had begun operating in 1900 or earlier, and some began operating as early as 1800 -more than 170 years before any sort of guidance on environmental protection was available. As of 2016, the NPL includes approximately 60 mine sites with diverse mining histories. Table B2 is a list of these mine sites, including the dates for 
Table B2. Historical summary of mine sites placed on the U.S. Environmental Protection Agency's National Priorities List.

[EPA, U.S. Environmental Protection Agency; ID, identification; NPL, National Priorities List; n.a., not applicable]

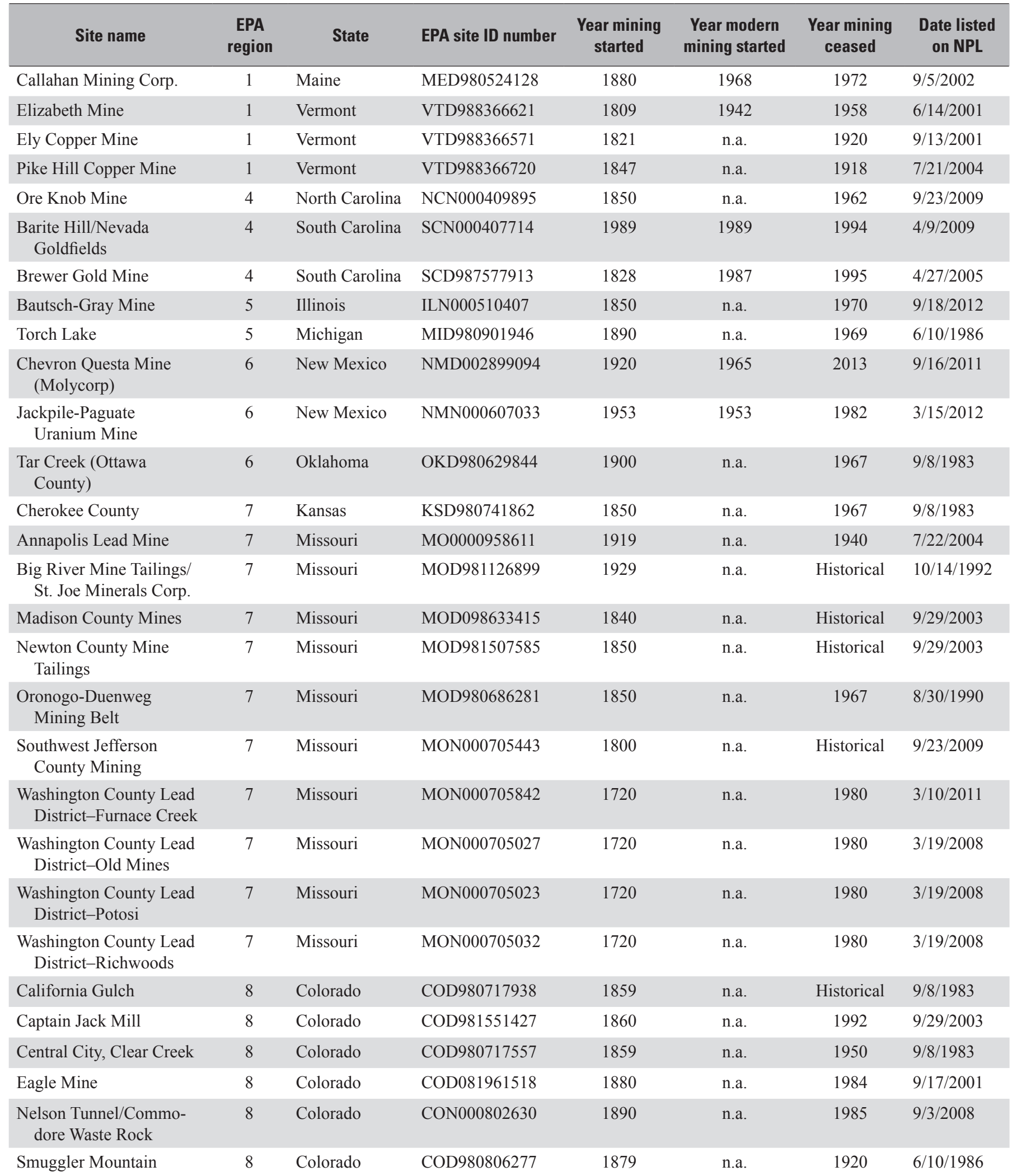


Table B2. Historical summary of mine sites placed on the U.S. Environmental Protection Agency's National Priorities List.-Continued [EPA, U.S. Environmental Protection Agency; ID, identification; NPL, National Priorities List; n.a., not applicable]

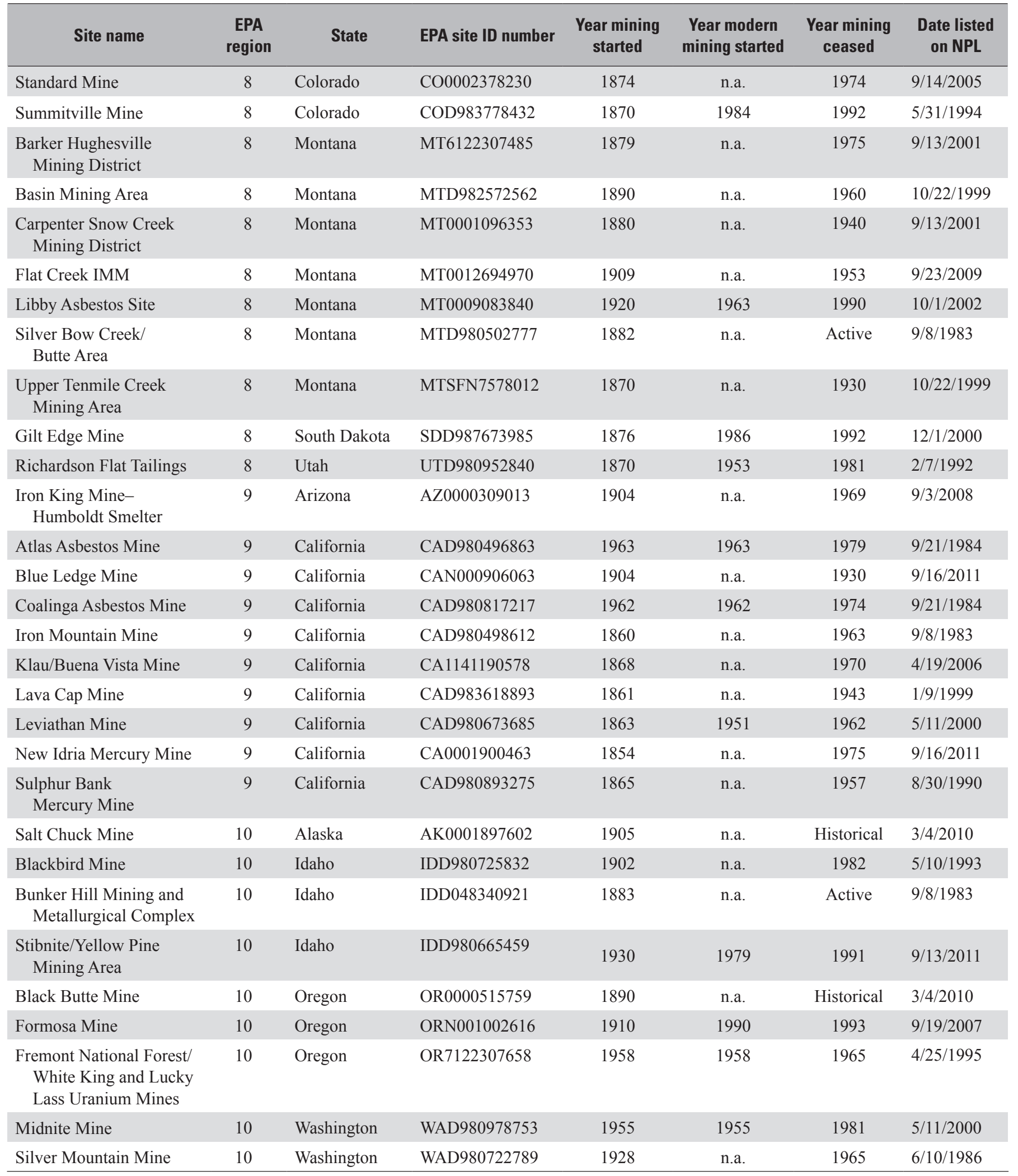


the historical start of mining, the start of modern-style mining, the end of mining (that is, when mining stopped), and the mine site's year of placement on the NPL. Figure B2 shows this information in graphical form.

A few of the sites, such as the Coeur d'Alene mining district in Idaho (Bunker Hill) and the Butte mining district in Montana, have been mined more or less continuously since the late 1800 s. Other historical mines saw early production and then became inactive because of ore depletion or significant decreases in metal prices, only to restart in modern times once metal prices increased or technological advances made production economically viable once again. Other sites began modern-style mining but before environmental protection requirements were in place (that is, before 1970). The term "modern-style mining" generally refers to mines that began operation after 1940, and is meant to include such practices as froth flotation for separation of ore concentrates as opposed to the hand-sorting of ores employed historically, and cyanide leaching of gold as opposed to mercury amalgamation. A final group of mines on the NPL is the set that went through the NEPA process for permitting.

The first mine that was permitted through the NEPA process (Summitville, Colorado) began operation under a new permit in 1984 and was designated as a Superfund site (placed on the NPL) in 1994 (table B2; fig. B2). Another mine permitted in 1979 (Stibnite/Yellow Pine, Idaho) was not listed on the NPL until 2011. For the mines listed on the NPL, the shortest time between the start of production and listing on the NPL is 3 years (Formosa, Oregon), and the longest time is 32 years (Stibnite/Yellow Pine, Idaho). The most recent mine to be permitted through the NEPA process and placed on the NPL began operation in 1990. No new mine permitted in the United States since 1990 has had significant enough environmental issues to warrant placement on the NPL, even though numerous mines have gone into production since 1990 (Long and others, 2010, p. 22).

For more than two decades, the quest for best environmental practices associated with mining has seen an increased level of coordination and cooperation among public and private stakeholders. It has motivated mining companies, government regulatory agencies, government land management agencies, government science agencies, and academia to work together to identify, investigate, and promote environmental best practices in mining. The level of cooperation among mining companies in this effort is especially notable because the companies seek competitive advantages over one another in most other aspects of their businesses. Collaborations on environmental best practices are generally made through consortia that involve various groups of stakeholders, professional conferences that facilitate the exchange of

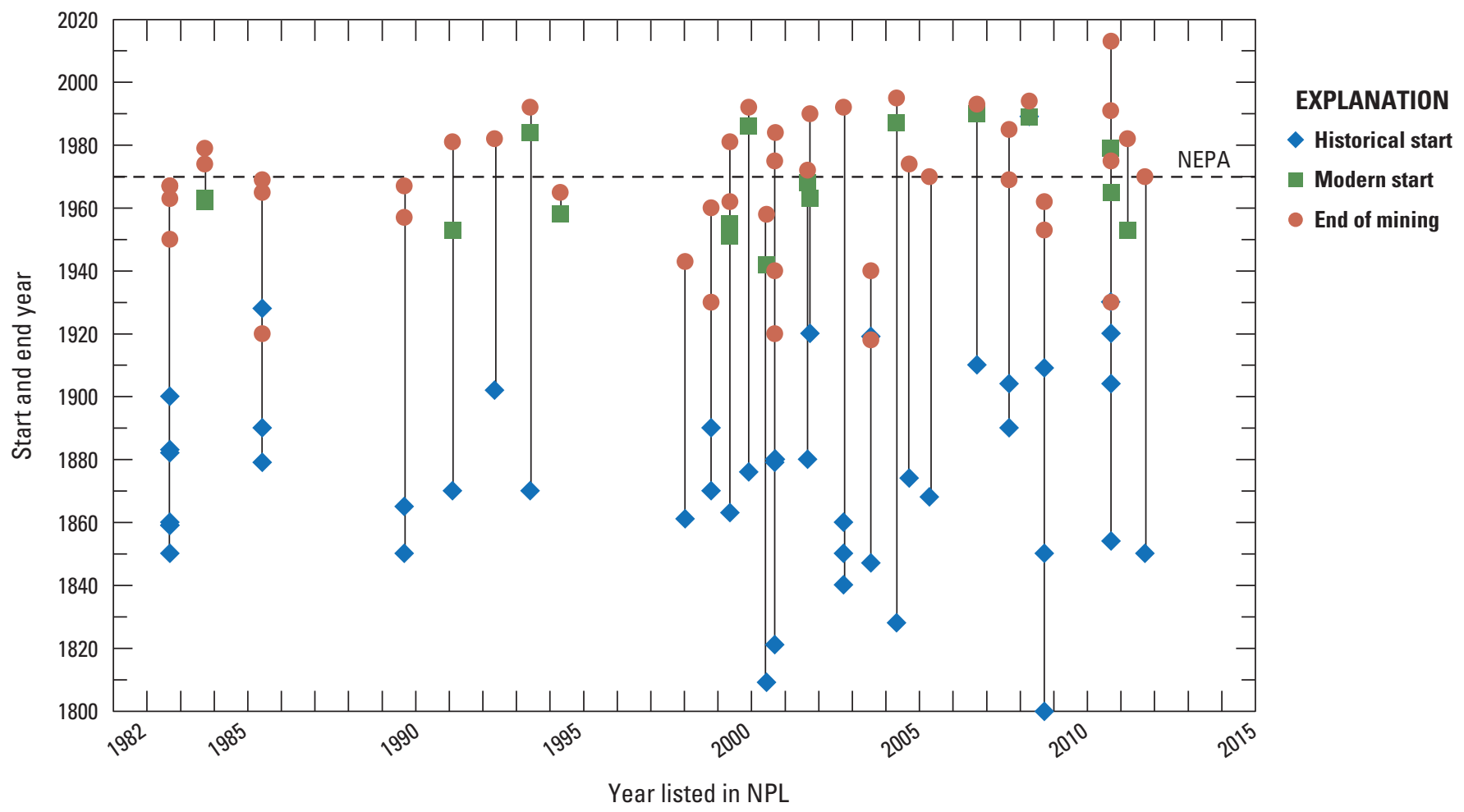

Figure B2. Graph showing dates associated with all the mine sites on the U.S. Environmental Protection Agency's National Priorities List (NPL). Dates, which correspond to those listed in table B2, include the historical start of mining, the start of modern-style mining, the end of mining, and the date of placement on the NPL. Vertical lines connect the dates for individual sites. The figure includes sites that started operation before the enactment of the National Environmental Policy Act (NEPA) of 1969 (42 U.S.C. $\$ 4321$ et seq.) as well as the one that started operating after its enactment. 
information, technology transfer efforts through workshops and other training courses, knowledge-gap-driven research, and the publication of print and Web-based resources.

Membership in these consortia spans the range of from highly selective membership to open membership (table B3). At the highly selective end are such groups as the International Network for Acid Prevention (INAP), which is made up of representatives from major mining companies. More inclusive organizations, such as the Canadian Mine Environment Neutral Drainage (MEND) program or the American Acid Drainage Technology Initiative (ADTI), include the mining industry, their consultants, government agencies at all levels, nongovernment organizations, and academia. Because of their overlapping goals, these consortia interact extensively, mostly through jointly sponsored professional conferences.

Numerous "best practices" publications and case studies have resulted from the efforts of these consortia. For example, the INAP produced its online Global Acid Rock Drainage Guide (GARD Guide), which describes best practices for the prediction, prevention, and management of drainage produced from sulfide mineral oxidation, including metal leaching and acid generation (International Network for Acid Prevention, 2014). Canada's MEND program releases best practices and case study reports on its Web site (http://mend-nedem.org).
The American ADTI publishes a series of workbooks on management technologies for waters affected by metal mining. To date, topics include the basics of metal-mining-influenced water (McLemore, 2008); the mitigation of metal-mininginfluenced water (Gusek and Figueroa, 2009); and the characteristics, predictive modeling, and sustainability of mine pit lakes (Castendyk and Eary, 2009). Other workbooks are in preparation.

\section{Mine Permitting and Planning Process Overview}

Mine permitting is a laborious process that must consider not only planning for mine development, but also planning for environmental protection during mining and after mine closure. The permitting process varies, depending on whether the mine will be located on private land, State land, or Federal land, although many aspects of the permitting process are similar among the location types.

In the United States, numerous permits are required to identify, develop, operate, and close a mine (Arizona Department of Mines and Mineral Resources, 2015). For State and Federal lands, permits may also be needed for

Table B3. Selected consortia devoted to identifying and implementing environmental best practices associated with mining.

\begin{tabular}{|c|c|c|c|c|}
\hline Consortium & Host country & $\begin{array}{l}\text { Founding } \\
\text { year }\end{array}$ & Membership & Focus \\
\hline $\begin{array}{l}\text { Acid Drainage Technology } \\
\text { Initiative (ADTI) } \\
\text { http://www.osmre.gov/ } \\
\text { programs/tdt/adti.shtm }\end{array}$ & United States & $\begin{array}{l}1995 \text { (coal); } \\
1998 \text { (metals) }\end{array}$ & $\begin{array}{l}\text { Mining industry, government, } \\
\text { academia, nongovernmental } \\
\text { organizations }\end{array}$ & $\begin{array}{l}\text { Promote advances in acidic drainage } \\
\text { prediction, prevention, control, } \\
\text { sampling and monitoring, and } \\
\text { treatment. Includes both coal and } \\
\text { metal mining sectors. }\end{array}$ \\
\hline $\begin{array}{l}\text { International Council on Mining } \\
\text { and Metals (ICMM) } \\
\text { http://www.icmm.com/ }\end{array}$ & International & 2001 & $\begin{array}{l}\text { Mining companies, industry } \\
\text { associations }\end{array}$ & $\begin{array}{l}\text { Sustainable development perfor- } \\
\text { mance in the mining and } \\
\text { metals industries. }\end{array}$ \\
\hline $\begin{array}{l}\text { Mine Environment Neutral } \\
\text { Drainage (MEND) } \\
\text { http://mend-nedem.org }\end{array}$ & Canada & 1989 & $\begin{array}{l}\text { Mining industry, Federal and } \\
\text { Provincial governments, } \\
\text { academia, nongovernment } \\
\text { organizations }\end{array}$ & $\begin{array}{l}\text { Develop technologies to prevent } \\
\text { and control acidic drainage. }\end{array}$ \\
\hline $\begin{array}{l}\text { Partnership for Acid Drainage } \\
\text { Remediation in Europe } \\
\text { (PADRE) } \\
\text { http://www.padre.imwa.info }\end{array}$ & Europe & 2003 & $\begin{array}{l}\text { Mining industry, government, } \\
\text { academia, nongovernmental } \\
\text { organizations }\end{array}$ & $\begin{array}{l}\text { Promote dissemination of knowledge } \\
\text { of current best practices and } \\
\text { innovations relating to acidic } \\
\text { drainage prediction, prevention, } \\
\text { and remediation with a } \\
\text { European emphasis. }\end{array}$ \\
\hline
\end{tabular}


mineral exploration. Permits for groundwater use, surfacewater use, and wastewater treatment and discharge are also required. These permits are designed to protect water quality and quantity in groundwater aquifers, streams, lakes, and wetlands. They cover all aspects of water management at a mine site. The storage and use of chemicals, explosives, fuel, and oil at mine sites require a number of permits. Lease agreements must be established that include a geologic evaluation; an economic feasibility study; an environmental assessment; and mine operation, reclamation, and closure plans. The agreements must also include archeological and biological surveys. A number of permits govern water and solid-waste management at mine sites. A variety of air-quality permits may be required to cover emissions and dust. Permits also cover flood control, construction, and worker safety, among other aspects of mine operation.

Bonding, also known as financial assurance, is an important part of the mine permitting process. Companies are required to furnish a bond to cover the estimated costs of mine reclamation and closure. Financial assurance is a topic of significant concern during mine permitting because of the difficulty in making accurate estimates of reclamation and closure costs. Mining companies prefer to have bonds set as low as possible, whereas regulators seek to ensure that bonds are adequate for successful reclamation. A notable example of an inadequate bond is the Summitville Mine, which is a heap-leach gold-mining operation in Colorado. Galactic Resources Ltd. declared bankruptcy in 1992 and abandoned the site. The bond was $\$ 4.7$ million, and although the EPA and the State of Colorado obtained an additional \$28 million from the bankruptcy proceedings, the total cost of the cleanup has exceeded $\$ 150$ million, which has been funded mostly through Federal and State taxes (Warhurst and Mitchell, 2000).

The time required to permit, construct, and commission a mine in the United States can be significant. Long and others (2010, p. 22) summarized the permitting and production history for recent mines (including uranium) in the United States. The time from the start of permitting to initial production ranged from 2 to 22 years and averaged approximately 10 years. The comprehensive regulatory environment in the United States requires environmental studies, due diligence for financing, permit application and approval, and public participation at multiple steps in the process, each contributing to the time from the start of the process to initial production. This timeframe for permitting encompasses the time needed to discover and develop an orebody and to conduct the engineering studies necessary to design and build a mine.

\section{Geoenvironmental Models}

The environmental footprint of a mine is complex and depends upon a number of factors. Mine design, environmental protection planning, and closure must all be customized to the unique geologic and geographical characteristics of the deposit to be mined. In many cases, the quest for best environmental practices can obscure the important influences that the geologic characteristics of an ore deposit have on its environmental behavior. A means of linking the geologic characteristics of a mineral deposit to its potential environmental effects, either in its undeveloped state or as a mine, is through the "geoenvironmental model" concept developed by the U.S. Geological Survey (USGS). A geoenvironmental model of a mineral deposit is defined as "a compilation of geologic, geochemical, geophysical, hydrologic, and engineering information pertaining to the environmental behavior of geologically similar mineral deposits (a) prior to mining, and (b) resulting from mining, mineral processing, and smelting" (Plumlee and Nash, 1995, p. 5; Seal and Hammarstrom, 2003). Geoenvironmental models are currently largely descriptive in nature. They represent empirical compilations of data that provide a powerful predictive capability of possible ranges of environmental signatures. The models are best used as guidelines for potential ranges of environmental challenges that may apply to the site. They provide guidance for the early stages of mine development (prefeasibility stage) to be supplanted by site-specific data collected after a resource has been identified.

The geologic characteristics of a mineral deposit type influence approaches for mineral production, which, in turn, influence the potential environmental impacts. Geologic factors include the geographic distribution of mineral deposits; the depth of the mineral deposit; the mineralogy of the deposit; the grain size of the ore minerals; the ore grade; and the tonnage of ore (DeYoung and Singer, 1981). Climate is also an important factor in determining the environmental characteristics of a mineral deposit. Mineral deposits that are developed in wet climates have a greater probability of affecting surface-water resources, whereas impacts to groundwater resources are a greater concern in arid climates. The depth of the deposit dictates whether it will be developed by underground or open pit mining methods. Open pit mines require greater volumes of waste rock to be removed to access the ore. The mineralogy of the ore determines a number of the environmental properties of the ore and waste, such as their acid-generating potential. Pyritic waste rock requires special management to mitigate acid mine drainage. The grain size of the ore influences the distinction between ore and waste because fine grinding may be cost prohibitive. More grinding also increases the energy requirements for a mine, and therefore, its carbon footprint. The ore grade determines how much of the processed ore becomes waste. Further, the environmental footprint of a mineral deposit varies with its stage of mineral production; at the exploration stage, potential environmental impacts are the lowest, but the potential impact increases through the mine-development stage to the mineral-production (mining) stage (Eggert, 1994).

The USGS has been developing geoenvironmental mineral deposit models for more than two decades. Preliminary 
models were completed in 1995 (du Bray, 1995). Since then, individual deposit models have been refined, such as those for base- and precious-metal massive sulfide deposits and gold deposits (Seal and Hammarstrom, 2003). Furthermore, environmental features of mineral deposits have been included in updated mineral deposit models for a variety of mineral deposits, including Mississippi Valley-type lead-zinc deposits (Leach and others, 2010); porphyry copper deposits (John and others, 2010); volcanogenic massive sulfide deposits (Shanks and Thurston, 2012); porphyry molybdenum deposits (Taylor and others, 2012); stratiform chromite deposits (Schulte and others, 2012); beryllium deposits (Foley and others, 2012); sedimentary-hosted cobalt-copper-gold deposits (Slack, 2013); nickel-cobalt laterite deposits (Marsh and others, 2013); rare-earth-element deposits (Verplanck and others, 2014); and magmatic nickel-copper-(platinum-group-element) deposits (Schulz and others, 2014).

\section{Future Trends}

Future trends in mining will likely have major implications for environmental protection-some positive and some negative. Some of these trends are the result of the increasing challenge inherent in making new discoveries coupled with increased demand for mineral commodities and the associated increase in the price of those commodities. Other trends are the result of a desire for more sustainable mining practices. These trends include the move toward the mining of lowerore-grade, large-tonnage deposits; increasing awareness of the carbon footprint of mining operations; and addressing the water requirements for larger scale mining operations in a context of predicted global increases in drought conditions resulting from climate change.

The trend to mine lower grade, larger tonnage deposits is motivated by several factors (Mudd, 2007a, b; 2010). One is the depletion of high-grade deposits near Earth's surface, which has driven explorers to seek deposits at greater depth and (or) of lower grade. The lower grades necessitate finding deposits of larger size to achieve greater economies of scale. The economic feasibility of mining lower grade deposits has also been made possible by technological breakthroughs, such as solvent extraction and electrowinning of low-grade copper ore (a heap-leaching technique), in situ leaching for uranium, carbon-in-pulp extraction of gold, and other hydrometallurgical techniques. From an environmental perspective, these techniques will likely lead to larger waste rock piles and tailings storage facilities that will require mitigation and long-term management. Other trends that have important environmental ramifications include the use of more cyanide at gold mines, increased energy use, and increased water use.

Increased energy use is correlated with increased greenhouse-gas emissions (Mudd, 2007b, 2010). This correlation has raised concerns about greenhouse-gas emissions associated with mining and the carbon footprint of mining in general. The desire to lower the carbon footprint of mining has motivated recent research in the feasibility of storing carbon dioxide in mine waste through mineral-carbonation reactions. Mine waste that contains magnesium-silicate minerals appears to be the most amenable for carbon sequestration through the engineered formation of magnesium-carbonate minerals. Candidate mine wastes include those from platinum-groupmetal deposits, magmatic nickel-copper deposits, asbestos deposits, and diamond deposits (Rollo and Jamieson, 2006; Pronost and others, 2011; Vogeli and others, 2011; Assima and others, 2014). The volume of this material may contribute to the development of "carbon-neutral" mines in the future.

Water management is an important issue at mines, both because of the quantity of water used at mines and the potential effect of mining on water quality. Resolving this issue is likely to become more pressing in the future if the frequency of droughts increases owing to climate change, as is widely predicted. A number of factors influence water use at mines, including climate, the ore-processing method used, mine design (for example open pit, underground, and in situ leaching), mine size, and material transport (for example, by slurry pipeline or by truck). There is a strong correlation between lower grade ores and increased water use for base (copper, lead, nickel, and zinc) and precious-metal (gold, silver, and platinum-group metal) mines, uranium mines, and diamond mines (Mudd, 2008). Thus, the trend toward mining lower grade ores is likely to result in increased water use at future mine sites and to have greater impacts on water availability in areas around mines.

\section{Summary}

Although the connection between society and mining began in the Stone Age when human ancestors first began fashioning tools from stone, policies and laws for managing the impact of mining on the environment have been in place for only a few decades. The steady and rapid growth of the global population since the start of the Industrial Revolution means that the amount of land available to provide for all our material needs is continuing to decrease on a per capita basis. With this increasing population comes increased demand for mineral resources, and meeting this demand is likely to become more challenging as near-surface high-grade deposits are depleted. A future trend with respect to mining will probably be toward the mining of larger deposits with lower grade ores. This trend will pose new environmental challenges, including how to manage greater volumes of mine waste, how to deal with increased greenhouse gas emissions resulting from the mining of larger volumes of ore, and how to address the increased water-resource needs of larger scale mines while still meeting the water requirements of areas near the mine for such uses as agriculture, drinking water, and sanitation. 


\section{References Cited}

Note: All Web links listed were active as of the access date but may no longer be available.

Agricola, Georgius, 1950, De re metallica [On the nature of metals (minerals)] (H.C. Hoover and L.H. Hoover, trans.): New York, N.Y., Dover Publications, 638 p. Original work published in 1556. [Also available at http://www.gutenberg.org/ files/38015/38015-h/38015-h.htm.]

Alpers, C.N., and Nordstrom, D.K., 2000, Estimation of premining conditions for trace metal mobility in mineralized areas, in ICARD 2000 - Fifth International Conference on Acid Rock Drainage, Proceedings, v. 1: Littleton, Colo., Society for Mining, Metallurgy, and Exploration, p. 463-472.

Arizona Department of Mines and Mineral Resources, comp., 2015, Arizona mining permitting guide ( $2 \mathrm{~d}$ ed.): U.S. Department of the Interior, Bureau of Land Management, Arizona State Office, May, 187 p. [Also available at https://www.blm.gov/sites/blm.gov/files/documents/files/ az-mine-permit-guide.pdf.]

Assima, G.P., Larachi, Faïçal, Molson, John, and Beaudoin, Georges, 2014, Comparative study of five Québec ultramafic mining residues for use in direct ambient carbon dioxide mineral sequestration: Chemical Engineering Journal, v. 245, June 1, p. 56-64. [Also available at http://dx.doi.org/10.1016/j.cej.2014.02.010.]

Brundtland, G.H., 1987, Our common future-Report of the United Nations World Commission on Environment and Development: Oxford, United Kingdom, Oxford University Press, 59 p. [Also available at www.un-documents.net/ our-common-future.pdf.]

Castendyk, D.N., and Eary, L.E., eds., 2009, Mine pit lakesCharacteristics, predictive modeling, and sustainability: Littleton, Colo., Society for Mining, Metallurgy, and Exploration, Management Technologies for Metal Mining Influenced Water Series, v. 3, 304 p.

DeYoung, J.H., Jr., and Singer, D.A., 1981, Physical factors that could restrict mineral supply, in Skinner, B.J., ed., Economic Geology — 75th anniversary volume, 1905-1980: Lancaster, Pa., Economic Geology Publishing Co., p. 939-954.

du Bray, E.A., ed., 1995, Preliminary compilation of descriptive geoenvironmental mineral deposit models: U.S. Geological Survey Open-File Report 95-831, 272 p. [Also available at http://pubs.usgs.gov/of/1995/ofr-95-0831/.]

Eggert, R.G., 1994, Mining and the environment-An introduction and overview, in Eggert, R.G., ed., Mining and the environment - International perspectives on public policy: Washington, D.C., Resources for the Future, p. 1-15.
Espejo, Lesly, Kretschmer, Nicole, Oyarzún, Jorge, Meza, Francisco, Núñez, Jorge, Maturana, Hugo, Soto, Guido, Oyarzo, Paula, Garrido, Marcela, Suckel, Felipe, Amezaga, Jaime, and Oyarzún, Ricardo, 2012, Application of water quality indices and analysis of the surface water quality monitoring network in semiarid north-central Chile: Environmental Monitoring and Assessment, v. 184, no. 9, p. 5571-5588. [Also available at http://dx.doi.org/10.1007/s10661-011-2363-5.]

Foley, N.K., Hofstra, A.H., Lindsey, D.A., Seal, R.R., II, Jaskula, Brian, and Piatak, N.M., 2012, Occurrence model for volcanogenic beryllium deposits, chap. F of Mineral deposit models for resource assessment: U.S. Geological Survey Scientific Investigations Report 2010-5070-F, 43 p. [Also available at http://pubs.usgs.gov/sir/2010/5070/f/.]

Gusek, J.J., and Figueroa, L.A., eds., 2009, Mitigation of metal mining influenced water, v. 2: Littleton, Colo., Society for Mining, Metallurgy and Exploration, 164 p.

International Network for Acid Prevention, 2014, Global acid rock drainage guide: International Network for Acid Prevention, accessed April 13, 2016, at http://www.gardguide.com.

John, D.A., Ayuso, R.A., Barton, M.D., Blakely, R.J., Bodnar, R.J., Dilles, J.H., Gray, Floyd, Graybeal, F.T., Mars, J.C., McPhee, D.K., Seal, R.R., Taylor, R.D., and Vikre, P.G., 2010, Porphyry copper deposit model, chap. B of Mineral deposit models for resource assessment: U.S. Geological Survey Scientific Investigations Report 2010-5070-B, 169 p. [Also available at http://pubs.usgs.gov/sir/2010/5070/b/.]

Kelley, R.L., 1956, The mining debris controversy in the Sacramento Valley: Pacific Historical Review, v. 25, no. 4, p. 331-346.

Kierstead, M.A., 2001, History and historical resources of the Vermont copper belt, in Hammarstrom, J.M., and Seal, R.R., II, eds., Environmental geochemistry and mining history of massive sulfide deposits in the Vermont copper belt: Society of Economic Geologists Guidebook Series, v. 35, part II, p. 165-192.

Leach, D.L., Taylor, R.D., Fey, D.L., Diehl, S.F., and Saltus, R.W., 2010, A deposit model for Mississippi Valleytype lead-zinc ores, chap. A of Mineral deposit models for resource assessment: U.S. Geological Survey Scientific Investigations Report 2010-5070-A, 52 p. [Also available at http://pubs.usgs.gov/sir/2010/5070/a/.]

Leblanc, M., Morales, J.A., Borrego, J., and Elbaz-Poulichet, F., 2000, 4,500-year-old mining pollution in southwestern Spain-Long-term implications for modern mining pollution: Economic Geology, v. 95, p. 655-662. [Also available at http://dx.doi.org/10.2113/gsecongeo.95.3.655.] 
Lee, C.S.L., Qi, S.-H., Zhang, G., Luo, C.-L., Zhao, L.Y.L., and Li, X.-D., 2008, Seven thousand years of records on the mining and utilization of metals from lake sediments in central China: Environmental Science and Technology, v. 42, no. 13, p. 4732-4738. [Also available at http://dx.doi.org/10.1021/es702990n.]

Long, K.R., Van Gosen, B.S., Foley, N.K., and Cordier, Daniel, 2010, The principal rare earth elements deposits of the United States - A summary of domestic deposits and a global perspective: U.S. Geological Survey Scientific Investigations Report 2010-5220, 96 p. [Also available at http://pubs.usgs.gov/sir/2010/5220/.]

Lottermoser, B.G., 2010, Mine wastes-Characterization, treatment, and environmental impacts ( $3 \mathrm{~d}$ ed.): Berlin, Germany, Springer-Verlag, 400 p. [Also available at http://dx.doi.org/10.1007/978-3-642-12419-8.]

Marsh, Erin, Anderson, Eric, and Gray, Floyd, 2013, Nickelcobalt laterites - A deposit model: U.S. Geological Survey Scientific Investigations Report 2010-5070-H, 38 p. [Also available at http://pubs.usgs.gov/sir/2010/5070/h/.]

McLemore, V.T., ed., 2008, Basics of metal mining influenced water-Management technologies for metal mining influenced water, v. 1: Littleton, Colo., Society for Mining, Metallurgy and Exploration, 103 p.

Mudd, G.M., 2007a, An analysis of historic production trends in Australian base metal mining: Ore Geology Reviews, v. 32, nos. 1-2, p. 227-261. [Also available at http://dx.doi.org/10.1016/j.oregeorev.2006.05.005.]

Mudd, G.M., 2007b, Global trends in gold mining-Towards quantifying environmental and resource sustainability: Resources Policy, v. 32, nos. 1-2, p. 42-56. [Also available at http://dx.doi.org/10.1016/j.resourpol.2007.05.002.]

Mudd, G.M., 2008, Sustainability reporting and water resources - A preliminary assessment of embodied water and sustainable mining: Mine Water and the Environment, v. 27, no. 3, p. 136-144. [Also available at http://dx.doi.org/ 10.1007/s10230-008-0037-5.]

Mudd, G.M., 2010, The environmental sustainability of mining in Australia-Key mega-trends and looming constraints: Resources Policy, v. 35, no. 2, p. 98-115. [Also available at http://dx.doi.org/10.1016/j.resourpol.2009.12.001.]

Nordstrom, D.K., 2008, Questa baseline and pre-mining ground-water quality investigation. 25. Summary of results and baseline and pre-mining ground-water geochemistry, Red River Valley, Taos County, New Mexico, 2001-2005: U.S. Geological Survey Professional Paper 1728, 111 p. [Also available at http://pubs.usgs.gov/pp/1728/.]
Plumlee, G.S., and Nash, J.T., 1995, Geoenvironmental models of mineral deposits - Fundamentals and applications, chap. 1 of du Bray, E.A., ed., Preliminary compilation of descriptive geoenvironmental mineral deposit models: U.S. Geological Survey Open-File Report 95-831, p. 1-9. [Also available at http://pubs.usgs.gov/of/1995/ofr-95-0831/.]

Pronost, Julie, Beaudoin, Georges, Temblay, Joniel, Larachi, Faïçal, Duchesne, Josée, Hébert, Réjean, and Constantin, Marc, 2011, Carbon sequestration kinetic and storage capacity of ultramafic mining waste: Environmental Science and Technology, v. 45, no. 21, p. 9413-9420. [Also available at http://dx.doi.org/10.1021/es203063a.]

Quinn, M.-L., 1993, Industry and environment in the Appalachian Copper Basin, 1890-1930: Technology and Culture, v. 34, no. 3, p. 575-612. [Also available at http://www.jstor.org/stable/3106705.]

Rollo, H.A., and Jamieson, H.E., 2006, Interaction of diamond mine waste and surface water in the Canadian Arctic: Applied Geochemistry, v. 21, no. 9, p. 1522-1538. [Also available at http://dx.doi.org/10.1016/j.apgeochem.2006.05.008.]

Rosman, K.J.R., Chisholm, Warrick, Hong, Sungmin, Candelone, J.-P., and Boutron, C.F., 1997, Lead from Carthaginian and Roman Spanish mines isotopically identified in Greenland ice dated from 600 B.C. to 300 A.D.: Environmental Science and Technology, v. 31, no. 12, p. 3413-3416. [Also available at http://dx.doi.org/10.1021/ es970038k.]

Rutland, R.W.R., 1997, The sustainability of mineral use: AGSO Journal of Australian Geology and Geophysics, v. 17, no. 1, p. 13-25. [Also available at http://www.ga.gov.au/ corporate_data/81474/Jou1997_v17_n1_p013.pdf.]

Schulte, R.F., Taylor, R.D., Piatak, N.M., and Seal, R.R., II, 2012, Stratiform chromite deposit model: U.S. Geological Survey Scientific Investigations Report 2010-5070-E, 131 p. [Also available at http://pubs.usgs.gov/sir/2010/5070/e/.]

Schulz, K.J., Woodruff, L.G., Nicholson, S.W., Seal, R.R., II, Piatak, N.M., Chandler, V.W., and Mars, J.L., 2014, Occurrence model for magmatic sulfide-rich nickelcopper-(platinum-group element) deposits related to mafic and ultramafic dike-sill complexes, chap. I of Mineral deposit models for resource assessment: U.S. Geological Survey Scientific Investigations Report 2010-5070-I, 80 p. http://dx.doi.org/10.3133/sir20105070I.

Seal, R.R., II, and Hammarstrom, J.M., 2003, Geoenvironmental models of mineral deposits - Examples from massive sulfide and gold deposits, in Jambor, J.L., Blowes, D.W., and Ritchie, A.I.M., eds., Environmental aspects of mine wastes: Mineralogical Association of Canada Short Course Series, v. 31, p. 11-50. 
Seal, R.R., II, Kornfeld, J.M., Meier, A.L., and Hammarstrom, J.M., 2001, Geochemical settings of mine drainage in the Vermont copper belt, in Hammarstrom, J.M., and Seal, R.R., II, eds., Environmental geochemistry and mining history of massive sulfide deposits in the Vermont copper belt: Society of Economic Geologists Guidebook Series, v. 35, part II, p. 255-276.

Shanks, W.C. Pat, III, and Thurston, Roland, eds., 2012, Volcanogenic massive sulfide occurrence model, chap. C of Mineral deposit models for resource assessment: U.S. Geological Survey Scientific Investigations Report 2010-5070-C, 345 p. [Also available at http://pubs.usgs.gov/sir/2010/5070/c/.]

Shotyk, William, Cheburkin, A.K., Appleby, P.G., Fankhauser, Andreas, and Kramers, J.D., 1996, Two thousand years of atmospheric arsenic, antimony, and lead deposition recorded in an ombrotrophic peat bog profile, Jura Mountains, Switzerland: Earth and Planetary Science Letters, v. 145, nos. 1-4, p. E1-E7. [Also available at http://dx.doi.org/10.1016/S0012-821X(96)00197-5.]

Skinner, B.J., 1989, Resources in the 21 st century-Can supplies meet needs?: Episodes, v. 12, no. 3, p. 267-275.

Slack, J.F., ed., 2013, Descriptive and geoenvironmental model for cobalt-copper-gold deposits in metasedimentary rocks (ver. 1.1, March 14, 2014): U.S. Geological Survey Scientific Investigations Report 2010-5070-G, 218 p. [Also available at http://dx.doi.org/10.3133/sir20105070G.]

Taylor, R.D., Hammarstrom, J.M., Piatak, N.M., and Seal, R.R., II, 2012, Arc-related porphyry molybdenum deposit model, chap. D of Mineral deposit models for resource assessment: U.S. Geological Survey Scientific Investigations Report 2010-5070-D, 64 p. [Also available at http://pubs.usgs.gov/sir/2010/5070/d/.]

Tetra Tech, Inc., 2009, Red Dog Mine extension-Aqqaluk project-Final supplemental environmental impact statement, submitted to the U.S. Environmental Protection Agency: Anchorage, Alaska, Tetra Tech, Inc., 2 v., accessed June 3, 2015, at http://dnr.alaska.gov/mlw/ mining/largemine/reddog/.
U.S. Environmental Protection Agency, 2003, EPA and hardrock mining-A source book for industry in the Northwest and Alaska: Seattle, Wash., U.S. Environmental Protection Agency, 57 p., accessed June 3, 2015, at http://yosemite.epa.gov/ R10/WATER.NSF/Sole+Source+Aquifers/hardrockmining.

U.S. Environmental Protection Agency, 2015, SuperfundNational Priorities List (NPL): U.S. Environmental Protection Agency Web page, accessed April 13, 2016, at http://www2.epa.gov/superfund/superfund-nationalpriorities-list-npl.

U.S. Environmental Protection Agency, 2016, HRS toolbox: U.S. Environmental Protection Agency Web page, accessed April 13, 2016, at https://www.epa.gov/superfund/hrs-toolbox.

Verplanck, P.L., Van Gosen, B.S., Seal, R.R, and McCafferty, A.E., 2014, A deposit model for carbonatite and peralkaline intrusion-related rare earth element deposits: U.S. Geological Survey Scientific Investigations Report 2010-5070-J, 58 p. [Also available at https://dx.doi.org/10.3133/sir20105070j.]

Vogeli, J., Reid, D.L., Becker, M., Broadhurst, J., and Franzidis, J.-P., 2011, Investigation of the potential for mineral carbonation of PGM tailings in South Africa: Minerals Engineering, v. 24, no. 12, p. 1348-1356. [Also available at http://dx.doi.org/10.1016/j.mineng.2011.07.005.]

Warhurst, Alyson, and Mitchell, Paul, 2000, Corporate social responsibility and the case of Summitville Mine: Resources Policy, v. 26, no. 2, p. 91-102. [Also available at http://dx.doi.org/10.1016/S0301-4207(00)00019-2.] 
For more information concerning this report, please contact:

Mineral Resources Program Coordinator

U.S. Geological Survey

913 National Center

Reston, VA 20192

Telephone: 703-648-6100

Fax: 703-648-6057

Email: minerals@usgs.gov

Home page: https://minerals.usgs.gov

Prepared by the USGS Science Publishing Network Reston Publishing Service Center

Edited by J.C. Ishee

Illustrations by Caryl J. Wipperfurth

Layout by Caryl J. Wipperfurth and Cathy Y. Knutson

Posting by Angela E. Hall 
